\title{
7. ANÁLISE DOS QUESTIONÁRIOS
}

André Dias Pereira e Catarina Zamith de Almeida

Para atingir os objetivos do Projeto, foi decidido que o principal recurso de pesquisa empírica seria um Questionário, disponibilizado através da plataforma online do IJFDUC, dirigido a um número significativo de partes interessadas (instituiçóes de saúde, ONGs de defesa de direitos de pacientes, funcionários públicos, académicos) para recolher os necessários dados. Era importante para a Equipa apresentar um Projeto que não só refletisse a muito relevante análise teórica e concetual dos recursos bibliográficos e técnicos disponíveis, como Legislação e Literatura atualizadas, mas que fosse mais além e permitisse uma pesquisa empírica, incorporando dados recentemente recolhidos e a sua análise, que permitissem propor soluçôes de políticas públicas, viabilizando a construção de sistemas eticamente adequados para dar resposta às dificuldades trazidas pelas situaçôes de pandemia.

O referido Questionário inclui 44 questôes: a maioria delas implica respostas sim / não, embora algumas delas exigissem uma resposta mais detalhada, envolvendo a convocação da opinião do inquirido, combinando, assim, tanto uma perspetiva objetiva das questóes éticas convocadas, como também uma apreciação subjetiva dos problemas identificados.

Foram enviadas dezenas de questionários, nos diversos países e regiốes, a entidades selecionadas, tendo sido recebidos 41 Questionários, dos 5 Ordenamentos Jurídicos convocados, em diferentes áreas de atividade. A população de inquiridos segue o seguinte perfil: 
Quadiro 1 - Número de Inquiridos por Ordenamento Jurídico

\begin{tabular}{|c|c|c|c|c|}
\hline \multicolumn{5}{|c|}{ Número de Inquiridos por Ordenamento Jurídico } \\
\hline Angola & Brasil & Moçambique & Portugal & RAEM \\
\hline 8 & 15 & 5 & 7 & 6 \\
\hline \multicolumn{6}{|c|}{ Sem Submissão de Informação: 0} \\
\hline
\end{tabular}

Quadiro 2 - Número de Inquiridos por Área de Atividade

\begin{tabular}{|c|c|c|c|}
\hline \multicolumn{4}{|c|}{ Número de Inquiridos por Área de Atividade } \\
\hline Direito & Saúde & Administração & Outros \\
\hline 15 & 12 & 3 & 4 \\
\hline \multicolumn{4}{|c|}{ Sem Submissão de Informação: 7} \\
\hline
\end{tabular}

\section{Quadro 3 - Número de Inquiridos por Língua de Resposta}

\begin{tabular}{|c|c|}
\hline Número de Inquiridos por Língua de Resposta \\
\hline Português & Inglês \\
\hline 39 & 2 \\
\hline
\end{tabular}

Ocupando-se este Projeto, entre outros aspetos, da averiguação das questôes da Responsabilidade em Saúde Pública no Mundo Lusófono, o Questionário preparado pela Equipa não poderia deixar de começar por procurar entender a importância da saúde pública na organização do sistema de saúde de cada um dos países envolvidos.

Atentando no exemplo fornecido por Angola, os inquiridos afirmaram que a saúde pública se torna de particular importância sobretudo quando há necessidade de intervenção direta do Estado na saúde, atendendo às circunstâncias deste país, com "infraestruturas de saúde muito exíguas, poucos profissionais e pouca formaçáo". Revela-se a importância deste setor na formação, fazendo chegar às camadas mais fragilizadas da população informaçóes básicas sobre saúde e higiene. Além disso um inquirido menciona que "A falta de saneamento, condiçóes básicas de higiene e o facto de Angola ser uma zona endémica para transmissão de doenças infeciosas, torna a saúde pública fundamental". Neste país, vigora a Lei de Bases do Sistema Nacional de Saúde - Lei n. ${ }^{\circ}$ 21-B/92, de 28 de Agosto, estabelecendo a promoção e garantia da saúde pública como parte da atividade do Estado (artigo 1.\%/2). 
O Decreto Presidencial n. ${ }^{\circ} 11 / 95$, de 29 de dezembro, que fixa as competências do Ministério da Saúde em Moçambique, discorre sobre a responsabilidade deste orgão no âmbito da investigação e vigilância epidemiológica (artigo 3.\%/3), preocupando-se também com o estatuto dos indivíduos que possam comprometer a saúde pública (artigo 3. \%/6/d). Ainda neste país, destaca-se o papel do Instituto Nacional de Saúde, que exerce competências ao nível da prevenção e controlo de doenças epidémicas no contexto da Saúde Pública (conforme estatuído no artigo 4.\%) da Resolução n. ${ }^{\circ} 17 / 2018$, de 1 de junho, que aprova o Estatuto Orgânico do Instituto Nacional de Saúde). Este organismo compreende ainda a direção dos Laboratórios de Saúde Pública (artigo 19. ${ }^{\circ}$ ). Os inquiridos, embora considerando este setor fundamental, apontam a falta de financiamento como razão de não ter um papel mais preponderante na Saúde em Moçambique.

No Brasil, a Lei n. ${ }^{\circ}$ 8.080, de 19 de setembro de 1990, coloca no elenco das competências da direçáo nacional do Sistema Único de Saúde (SUS) definir e coordenar os sistemas da rede de laboratórios de saúde pública (artigo 16.\%/III/b)). O mesmo diploma é sensível às determinantes de saúde (artigo 3. ${ }^{\circ}$ ), estabelecendo como uma das prioridades do SUS a identificação e divulgação dessas determinantes (artigo 5.\%/I). A importância desta área da saúde é demonstrada ainda pela abundância de escolas de saúde pública, entre as quais se destaca a Escola Nacional de Saúde Pública Sérgio Arouca que, para além de se dedicar à investigação, cumpre uma importante função ao nível do ensino da Saúde Pública por meio de mestrados e doutoramentos.

Um inquirido testemunha que: "Caso não fosse o SUS, impossível seria conferir assistência aos 5570 municípios brasileiros. Além disso, em um cenário de escassez de recursos, assim como afetação importante do emprego e renda com as medidas de isolamento social, sem a saúde pública podemos de modo verossímil vislumbrar a barbárie que seria pela prestação de assistência. Não sendo o bastante, ao observar a expansão da rede de saúde, verifica-se que a rede pública não mediu esforços para dar conta da pressão sobre o sistema, ao passo que a rede privada, por si só, não fez um esforço minimamente equivalente.”.

Outro inquirido refere que: "O SUS nasceu do movimento de reforma sanitária, iniciado nos anos 1970, e que por suas diretrizes de universalidade, descentralização e participação da comunidade encontrou eco na Constituiçáo Federal, de 1988, a partir de esforços de 
gestâo e de financiamento de todos os entes federais, caracterizando-se atualmente como a maior política social do país. O Sistema Único de Saúde do Brasil (SUS) atende a toda a população do território brasileiro, sendo que cerca de $25 \%$ (considerada a média nacional) possui plano/seguro privado de saúde para as açóes ambulatoriais e hospitalares - no todo ou em parte. Todavia, enquanto outros sistemas universais do mundo lutam pela consolidação (Canadá, Reino Unido, Portugal), o SUS ainda luta pela sobrevivência, cenário esse ainda mais agravado nos últimos anos considerado o desfinanciamento, além dos quadros de necessidade assistêncial ainda mais oneroso a ser dispendido durante a pandemia da Covid-19.”.

Em Portugal, a Saúde Pública tem relativa importância no currículo da Medicina português, existindo a especialidade de Médico Especialista em Saúde Pública (MSP) ${ }^{1}$, que pode atuar em várias áreas de intervenção do Sistema Nacional de Saúde (SNS), bem como exercer atividades de investigação junto de Universidades, na Indústria Farmacêutica ou Entidades Privadas. Os MSP são representados por uma Associação, a Associação Nacional de Médicos de Saúde Pública, fundada em 1987, a qual oferece oportunidades de formação, nomeadamente um curso de Pós-Graduação na área. A formação pós-graduada na área (mestrados, doutoramentos e outras especializações) é também oferecida pela Escola Nacional de Saúde Pública da Universidade Nova de Lisboa (ENSP-NOVA), pelo que se identificam em Portugal diferentes oportunidades para formaçáo na área, o que atesta a sua relevância. Neste país, os inquiridos entendem que a importância, antes da Pandemia, deste setor, era praticamente nula. Noutra perspetiva, alguns inquiridos esclarecem que a importância nunca foi colocada em causa: simplesmente a importância não era reconhecida ("[...] degradação, em meios e recursos, das unidades de saúde pública”) e a Saúde Pública não era valorizada. Metade dos inquiridos portugueses considera que a Saúde Pública é um pilar fundamental da organização do SNS português.

Um inquirido português revela que: "Sob tutela das Administraçóes Regionais de Saúde e consideradas unidades funcionais dos Agrupamentos de Centros de Saúde, as unidades de Saúde Pública, antes da pandemia da COVID-19, não eram valorizadas em termos de recursos humanos médicos, técnicos de saúde, enfermeiros e administrativos.

1 Nos termos da Portaria n. ${ }^{\circ}$ 141/2014 de 8 de julho. 
A carreira médica de Saúde Pública nunca foi considerada atrativa e as condiçóes do exercício da profissáo sempre foram insuficientes. Em Portugal, há apenas 350 médicos especialistas em Saúde Pública. Há zonas do País onde cada médico tem a seu cargo 12, 13 ou 14 concelhos. É uma situação que já está a ser revista mas de uma forma demasiado lenta.".

No que diz respeito à inclusão da Saúde Pública na Legislação, o Anteprojeto da Lei de Bases da Saúde, elaborado em 2018, por uma Equipa presidida pela Senhora Doutora Maria de Belém Roseira, colocava, quase em jeito premonitório, grande ênfase na problemática da Saúde Pública, dedicando integralmente o Capítulo III da Proposta ${ }^{2}$ (oito Bases, de grande desenvolvimento) a este tópico, versando sobre a centralidade da política de saúde na saúde pública e ainda, designadamente, sobre a necessidade de avaliação dos impactos na saúde pública das diferentes políticas (sociais, de trabalho, ambientais, de obras públicas, entre outras). Dedicou-se especificamente a Base XV às situaçóes de emergência em saúde pública, prevendo-se a possibilidade de requisição de profissionais e estabelecimentos de saúde, assim como a necessidade de atuação da Autoridade de Saúde em sintonia com entidades internacionais, permitindo a "[...] preparação para e na resposta a ameaças, deteção precoce, avaliação e comunicação de risco.” (Base XV/4).

Afastada essa Proposta de lei, identificam-se escassas referências à Saúde Pública no diploma atualmente em vigor, Lei n.o 95/2019 de 4 de setembro (que revogou a anterior Lei de Bases, já de 1990). A Base IV afirma que um dos fundamentos da Política de Saúde é a melhoria do estado de saúde da populaçáo, por meio, designadamente, de uma abordagem de saúde pública. É a Base X que se dedica especificamente a esta matéria, dispondo, sob a epígrafe "Saúde Pública":

1. Compete ao Estado acompanhar a evolução do estado de saúde da população, do bem-estar das pessoas e da comunidade, através do desenvolvimento e da implementação de instrumentos de observação em saúde.

2. O membro do Governo responsável pela área da saúde deve identificar áreas específicas de intervenção, programas e açôes de promoção da saúde e da prevenção da doença ao longo da vida,

2 Pode ser consultada, na sua íntegra, em: Cadernos da Lex Medicinae - n. ${ }^{\circ} 3 \mid$ Lei de Bases da Saúde - Materiais e razóes de um projeto, 2018, pp. 41 e seguintes. 
tendo presentes os problemas de saúde com maior impacto na morbilidade e na mortalidade, os desafios sociodemográficos e a existência de determinantes não modificáveis, bem como sociais, económicos, comerciais, ambientais, de estilo de vida e de acesso aos serviços.

Outras referências surgem no âmbito da genómica e da sua relevância para a Saúde Pública (Base XI, $1 .^{\circ}$ parágrafo), bem como na necessidade de presença da literacia para a saúde nas decisões sobre Saúde Pública (Base XI/2). Maior destaque é dado a esta matéria no elenco das competências da Autoridade de Saúde (Base XXXIV), cujas atribuições tiveram particular interesse no mitigar da Pandemia da SARS-Cov-2. A necessidade de avaliação do impacto de programas, planos ou projetos, públicos ou privados, que possam afetar a saúde pública é estatuída na Base XXXVII.

A RAEM, ao contrário de outras jurisdiçôes, dispunha já de uma base legal para fundamentar as medidas necessárias para controlar a Pandemia: a Lei n. ${ }^{\circ}$ 2/2004, para a prevenção, controlo e tratamento de doenças transmissíveis, publicada na sequência da crise de saúde gerada pela SARS em 2001-2003, que afetou Macau profundamente (cuja lista de doenças foi alterada pela Lei n. $\left.{ }^{\circ} 1 / 2016\right)$. Com base nesta lei, ainda antes da chegada dos primeiros casos a Macau, foi criado o Centro de Coordenação de Contingência do Novo Tipo de Coronavírus, com o objetivo de acompanhar a evolução da pandemia e implementar as medidas consideradas necessárias. Um outro dado que permite explicitar a relevância da saúde pública em Macau é a inclusão, na estrutura orgânico-funcional dos Serviços de Saúde de Macau (Decreto-Lei n. ${ }^{\circ}$ 81/99/M, de 15 de novembro), de um Laboratório de Saúde Pública (artigo 23. ${ }^{\circ}$ ), integrado num subsistema de cuidados de saúde generalizados (artigo 18. ${ }^{\circ}$ ), em cujas atribuiçóes se destaca "Programar e executar as acçóes necessárias ao melhor conhecimento, quer dos factores de risco para a saúde quer da situação epidemiológica, das afecçôes mais relevantes da comunidade e avaliar os respectivos resultados" (23. / / / a)).

Relativamente à Regiáo Administrativa, foi assinalado por um inquirido o facto de ser necessária no território uma política de saúde pública forte, atendendo ao facto de ser um destino turístico com milhóes de visitantes anuais, com centenas de trabalhadores que atravessam a fronteira com a China e Hong Kong todos os dias. Além disso, foi referido que este setor recebeu atenção acrescida depois da Pandemia 
da SARS de 2002. A totalidade dos inquiridos entende que a Saúde Pública é fundamental em Macau.

Partindo deste quadro, denota-se que no universo dos Países/Região Administrativa estudados, a SARS-CoV-2 veio acentuar a importância da saúde pública. Em Angola, novamente o destaque é para a situação económica e política do país: as debilidades económicas da população exigiram que na mitigação da Pandemia se adotassem políticas Estatais que reforçassem a proteção conferida aos cidadãos. Em Portugal, a Saúde Pública passou a surgir como protagonista diária das discussões políticas, condicionando as decisōes tomadas hodiernamente. Especialistas na matéria passaram a ser sistematicamente inquiridos relativamente ao impacto das políticas adotadas no desenvolvimento do número de casos e no avançar das "vagas" de contágio do vírus. Os inquiridos mostraram-se sensíveis a esta acentuação da relevância, tendo-se mencionado um "aumento exponencial da importância atribuída" e referindo-se que "Portugal 'acordou' para a importância destes serviços, que são a primeira linha de defesa contra epidemias e a primeira resposta aos problemas de saúde das populaçóes".

No campo normativo, as opçóes do legislador português foram condicionadas pela emergência da condicionante das preocupaçóes de Saúde Pública, a níveis tão distintos como na Responsabilidade Extracontratual do Estado, cujo regime é estatuído na Lei n. ${ }^{0}$ 67/2007, de 31 de dezembro, a qual consagra uma cláusula geral de indemnização pelo sacrificio, que visa ressarcir danos anormais e especiais, sendo "[...] especiais os danos ou encargos que incidam sobre uma pessoa ou um grupo, sem afetarem a generalidade das pessoas, e anormais os que, ultrapassando os custos próprios da vida em sociedade, mereçam, pela sua gravidade, a tutela do direito" (artigo 2. ${ }^{\circ}$ ). Havendo setores a ser desproporcionadamente afetados pelo Estado de emergência constitucional e sua regulamentação pelo Governo, é claro o "sacrifício" no atual contexto da Pandemia. Em derrogação deste direito de indemnização surge o Decreto-Lei 19-A/2020, de 30 de abril (que estabelece um regime excecional e temporário de reequilíbrio financeiro de contratos de execução duradoura, no âmbito da pandemia da doença COVID-19), cujo artigo $8 .^{\circ}$ afasta esta indemnização durante a pandemia da Covid-19, dispondo que: "Não dão lugar a indemnização pelo sacrifício os danos resultantes de atos regularmente praticados pelo Estado ou outra entidade pública, no exercício das competências conferidas pela 
legislação de saúde pública e de proteção civil, ou no quadro do estado de emergência, para efeitos da prevenção e do combate à pandemia COVID-19, que constitui para o efeito causa de força maior.”. Afigura-se problemática esta norma, questionando-se mesmo a sua constitucionalidade, sobretudo considerando o impacto económico das medidas mitigadoras da SARS-CoV-2. Transpondo o conteúdo da norma para o âmbito da Saúde, é inegável que existe um sacrifício para um cidadão que se vacina com vista à proteção da população em geral e que, pela sua decisão, poderá sofrer danos. Do mesmo modo, é sabido que os doentes não-covid têm sido especialmente prejudicados no direito de acesso ao tratamento, e no direito a tratamento em tempo útil, garantido aliás pela legislaçáo que fixa tempos máximos de espera para consultas e intervenções cirúrgicas ${ }^{3}$.

Dos 37 inquiridos que responderam claramente a esta questão, $38 \%$ revela que a Pandemia colocou em evidência as fragilidades dos sistemas nacionais de saúde; $60 \%$ entende que a Covid trouxe consigo um incremento exponencial da relevância Saúde Pública, permitindo à população compreender a necessidade de adoção de políticas de higiene e saúde universais, valorizando-se a figura do profissional de saúde e a prestação de cuidados de saúde, em geral.

A carreira de saúde pública no campo da Medicina surge, como já tivemos oportunidade de esclarecer, regulada em Portugal. Desde logo, neste país, o Decreto-Lei n. ${ }^{\circ}$ 177/2009, de 4 de agosto, estabelece o regime da carreira especial médica, bem como os respetivos requisitos de habilitação profissional, e estatui, no artigo 7.\%1, que, salvaguardada a possibilidade de integração de outras áreas de exercício profissional, existem à partida "[...] as áreas hospitalar, medicina geral e familiar, saúde pública, medicina legal e medicina do trabalho [...]" (sublinhado nosso). O programa de formação da área de especialização de Saúde Pública é regulado pela Portaria n. ${ }^{\circ} 141 / 2014$, de 8 de julho. Este plano inclui estágios em campos tão diversificados como saúde comunitária, investigação epidemiológica em saúde pública, ou auditoria em saúde pública. Entre as competências a adquirir, pretende-se que os internos dominem, entre outras áreas, as questôes de epidemiologia e controlo das doenças transmissíveis bem como tomem conhecimento dos fatores demográficos, sociais, biológicos e ambientais que influenciam a

3 Portaria n. ${ }^{o}$ 153/2017, de 4 de maio. 
saúde. Um inquirido esclarece que "no passado havia, de facto, 3 carreiras médicas: clínica geral, hospitalar e saúde pública”, Atualmente, não obstante, "Sendo integrada na carreira médica e sendo uma especialidade médica, a Saúde Pública, é como todas as restantes especialidades, regulada pela Ordem dos Médicos, dispondo de um colégio de especialidade próprio. Integra, a nível internacional, o board de Medicina de Saúde Pública ("Public Health Medicine") da Uniáo Europeia dos Médicos Especialistas (UEMS).”.

Do mesmo modo, na RAEM, a carreira médica de saúde pública surge prevista na Lei n. ${ }^{\circ}$ 10/2010 (artigo 8. $\left.{ }^{\circ} / 1 / 3\right)$ ). Um inquirido esclarece que a carreira médica em Macau inclui a medicina hospitalar, medicina geral, medicina de saúde pública, medicina dentária e medicina tradicional chinesa. Assim, há um ramo de saúde pública no internato complementar que habilita o médico para o exercício da especialidade de saúde pública (Decreto-Lei n. ${ }^{\circ}$ 8/99/M de 15 de Março).

No Brasil, para além da carreira do sanitarista (Portaria n. ${ }^{\circ} 256$, de 11 de março de 2013, artigo $5 .^{\circ}$ que o define como sendo um " [...] profissional de nível superior, graduado na área da saúde com pós-graduação em saúde pública ou coletiva, ou graduado em uma dessas áreas."), existe, complementarmente ${ }^{4}$, o profissional de saúde coletiva, cuja função implica uma visão mais alargada da saúde pública, que vai além das questóes epidemiológicas e que tem em atenção as outras áreas de conhecimento que afetam a saúde, nomeadamente as variantes sociais da saúde (habitação, educação, etc.). Estes profissionais não são graduados em Medicina, têm uma outra formação académica que lhes confere o grau de bacharelato em Saúde Coletiva. Trabalham na "área-meio" das instituições de saúde, assumindo funçóes de cariz administrativo, alertando, agora com a Pandemia, para as variantes que estão a afetar a resposta destas instituiçôes à Covid, recomendando uma atuação articulada das diferentes áreas. Trata-se de uma experiência que apresenta resultados muito positivos no Brasil e que, a nosso ver, poderia ser replicada noutros países. Assim, uma das recomendaçóes para os países envolvidos/RAEM, é a criação de uma figura equiparável ao técnico de saúde coletiva, desempenhada por profissionais com

${ }^{4}$ Fernando CUPERTINO. Transcrições do Workshop realizado no âmbito do Projeto, subordinado ao Tema: A Pandemia Covid-19 no Espaço da Lusofonia, retificadas e aprovadas pelo Orador. 
formação especializada (por exemplo, com formação de base de enfermagem ou por meio de um curso disponibilizado no ensino politécnico) que se ocupem de apoiar os médicos de saúde pública em situaçôes agudas de crise pandémica, nomeadamente exercendo funçôes de rastreio e planificando açóes como a administração de vacinas (determinaçáo de prioridades, por exemplo). Desenvolver uma ocupação específica nesta área pretende aliviar o desvio de profissionais de saúde especializados para funçóes de rastreio realizadas, por exemplo, como em Portugal, por via telefónica (SNS 24).

Em Angola e Moçambique, os inquiridos não parecem muito certos quanto à existência, ou não, dessa regulaçáo. No primeiro país, apenas 3 inquiridos respondem em sentido afirmativo. No segundo, o único inquirido que respondeu à questão, entende que esta carreira está regulada.

Dentro do Direito da Saúde, nem sempre a matéria da Saúde Pública é estudada. Em Angola, não há cursos de Direito que incluam o estudo da disciplina de Direito da Saúde, havendo, apenas, cursos pós graduados que culminam na produção de teses e dissertaçóes na área do Direito da Saúde. Se se olhar ao caso português, é preciso ter em conta que, à partida, o Direito da Saúde em si não é uma área do Direito que recebe grande atenção no universo jurídico, verificando-se, não obstante, recentemente, um crescente interesse, não só pela sua investigação, mas também prática jurídica, com escritórios de advogados a surgir com o Direito da Saúde como área exclusiva de atuação ou a incorporar esse âmbito no leque de áreas jurídicas mais clássicas. Atendendo à matéria de Saúde Pública em específico, poucas oportunidades de formação para os juristas vão surgindo. De destacar, nos últimos anos, dois cursos de Pós-graduação preparados pelo Centro de Direito Biomédico da Faculdade de Direito da Universidade de Coimbra (CDB): a primeira edição, em 2016, e a segunda, mais recentemente, em 2019, reunindo especialistas da área da Saúde e do Direito. Publicaçóes sobre a temática a mencionar são, desde logo, a Portuguese Journal of Public Health, anteriormente sob o título de Revista Portuguesa de Direito da Saúde, cuja responsabilidade de edição é da ENSP-NOVA.

No Brasil, os inquiridos relatam que se trata de uma disciplina oferecida por algumas instituiçóes que lecionam direito. Não obstante, surge mais frequentemente em cursos de especialização ou pós-graduação ou como disciplina não obrigatória na formação pós-graduada, pelo 
que os 12 inquiridos que responderam à questão, respondem em sentido afirmativo.

Dediquemos as próximas páginas à análise dos Sistemas de Saúde dos territórios envolvidos no Estudo. Quanto à caraterização, per se, destes Sistemas, opondo aqueles que assumem um caráter Bismarckiano (seguros obrigatórios) aos estruturados num formato Beveridgiano (financiado por impostos), poderemos dizer que o Sistema português é, indubitavelmente, um sistema misto ${ }^{5}$, combinando o SNS, financiado pelo Estado, com seguros privados contratualizados pelos cidadãos ${ }^{6}$. No Relatório de Evolução da Atividade Seguradora do 3.o Trimestre de 2020, publicado pela Autoridade de Supervisão de Seguros e Fundos de Pensóes (ASF), houve um crescimento de $8,9 \%$ na produção de seguro de Doença face a 2019, no ramo dos seguros não vida 7 . Estima-se que mais de 3,15 milhóes de portugueses usufruam de seguros de saúde. Já o SNS tem raiz na Constituição da República Portuguesa, especificamente no seu artigo $64 .^{\circ}$, o qual estabelece o direito à proteção da saúde, cujo número dois, alínea a), dispóe que este direito é designadamente realizado "Através de um serviço nacional de saúde universal e geral e, tendo em conta as condiçôes económicas e sociais dos cidadãos, tendencialmente gratuito;". O inciso "tendencialmente" colocado neste artigo autoriza a cobrança de taxas moderadoras ${ }^{8}$, atendendo aos limites e diretrizes que constam da Lei de Bases da Saúde,

5 Quanto à interação Estado-SNS-Privados, cfr: O Setor Da Saúde: Organização, Concorrência E Regulação, coord. António Mendes e Francisco André, Caleidoscópio e Confederação Empresarial de Portugal, 2017.

6 Sobre a articulação do Sistema Público e Privado é muito relevante e esclarecedor o Acórdão do Tribunal Constitucional n. ${ }^{\circ}$ 731/95, de 14 de dezembro [Relator: Conselheiro Alves Correia], que dispóe o seguinte: “[...] o texto constitucional não perfilhou um modelo de monopólio do sector público de prestação de cuidados de saúde — tendencialmente coincidente com o Serviço Nacional de Saúde —, antes admite a existência de um sector privado de prestação de cuidados de saúde em relação de complementaridade e até de concorrência com o sector público." (parágrafo 5.2).

7 Relatório disponível em: https://www.asf.com.pt/NR/rdonlyres/8BD33AE3-9A2D-4D8F-92D0-1EF3039A877E/0/REAS_3T2020_3.pdf (último acesso a $10 / 02 / 2021)$

8 Tem-se assistido ao abandono progressivo das Taxas Moderadoras, desde $1 \mathrm{de}$ janeiro de 2021, para além das isençóes já conhecidas, estas estáo dispensadas nas consultas de cuidados de saúde primários e também nos exames complementares de diagnóstico e terapêutica prescritos no âmbito da rede de prestação de cuidados de saúde primários e realizados no mesmo âmbito. 
Base 24. Do total dos gastos com a saúde, a OCDE estima que $66 \%$ da despesa seja suportada pelo Estado ${ }^{9}$, por via do financiamento direto do Governo ("government schemes") e seguros da segurança social. A mesma entidade denotou em Portugal, entre 2009 e 2017, um aumento de $3 \%$ dos quantitativos de gastos com saúde suportados pelos cidadãos "out-of-pocket". Na aquisição de medicamentos, a OCDE reporta que $55 \%$ dos gastos são suportados pelo Estado, $1 \%$ por seguradoras e $44 \%$ pelos cidadáos ${ }^{10}$. Assim, a presença dos seguros de saúde no sistema português tem sido crescente e tem aumentado a par e passo da evolução da Pandemia. O interesse nos seguros consolidou-se depois de se ter esclarecido que grande parte das seguradoras iam comparticipar nos custos do teste da Covid-19 (Multicare, Advancecare, Allianz, Médis, Montepio, Future Healthcare, Generali...), embora prevendo-se a necessidade de prescrição médica para estes testes. Outros custos, nomeadamente Kits de Proteção Médica (EPI), são comparticipados por algumas seguradoras, embora custos de internamento relacionados com a SARS-Cov-2, regra geral, não estão abrangidos pelas apólices, uma vez que as epidemias estão usualmente excluídas dos seguros de saúde. Dos 7 inquiridos portugueses, 3 consideram o sistema "misto" e 4 "beveridgiano".

O sistema angolano segue o mesmo modelo misto, surgindo, não obstante, o segmento Beveridgiano como maioritário. São poucas instituiçôes públicas que usam o sistema Bismarckiano, por oposição, no setor privado são as grandes empresas que usam o sistema Bismarckiano. Segundo Cristóvão Simôes ${ }^{11}$, Reitor da Universidade José Eduardo dos Santos, orador convidado no Workshop realizado no âmbito do presente Estudo, o sistema de saúde angolano é um Sistema de saúde frágil e insuficiente, caraterizado pelo número reduzido de unidades sanitárias, com escassos e pouco especializados profissionais.

9 Dados de 2017, disponíveis em: https://www.oecd-ilibrary.org/sites/7f66369c-en/index.html?itemId=/content/component/7f66369c-en (último acesso a 10/02/2021)

10 Dados de 2017, disponíveis em: https:/www.oecd-ilibrary.org/sites/3b2d8ac1-en/index.html?itemId=/content/component/3b2d8ac1-en (último acesso a 10/02/2021)

11 Cristóvão Simốes, Transcriçôes do Workshop realizado no âmbito do Projeto, subordinado ao Tema: A Pandemia Covid-19 no Espaço da Lusofonia, retificadas e aprovadas pelo Orador. 
Existe em Portugal um Sistema Público de Saúde, financiado pelo Estado. O Estatuto do SNS foi aprovado pelo Decreto-Lei n. ${ }^{\circ} 11 / 93$, de 15 de janeiro (atualmente em vigor na redaçáo dada pela Lei n. ${ }^{\circ} 82-B / 2014$, de 31 de dezembro), o qual se prevê que, não obstante a sua natureza Estadual, seja dividido em cinco regiōes de saúde, subdivididas em sub-regióes, por sua vez divididas em áreas de saúde (artigos $3 .^{\circ}, 4 .^{\circ}$ e $5 .^{\circ}$ do diploma). O financiamento do SNS está regulado pelos artigos $23 .^{\circ}$ e seguintes do Decreto: o Estado surge como responsável pelos encargos, a par, designadamente, dos utentes não beneficiários do SNS. O artigo $24 .^{\circ}$ explicitamente consagra a possibilidade de contratualização de seguros de saúde. Recentemente, o papel dos Municípios na gestão do SNS recebeu as alteraçóes que constam do Decreto Lei no 23/2019, de 30 de janeiro de 2019, que transferem para o Município, desde logo, competências para manutenção, conservação e equipamento das instalaçôes de unidades de prestação de cuidados de saúde primários. No entanto, apenas uma percentagem baixa de $\mathrm{Mu}-$ nicípios concordou assumir imediatamente estas responsabilidades no domínio da saúde, beneficiando do regime que permite efetivar esta transferência até 2021 (artigo 20.\%/2).

Também financiado pelo Estado, mas contando com apoio financeiro por meio de doaçóes de organizaçôes internacionais, como a OMS e a UE, surge o Sistema Nacional de Saúde (SNS) de Angola. A Lei de Bases do Sistema Nacional de Saúde contempla a possibilidade de o Estado contratar com entidades privadas para a prestação de cuidados de saúde à populaçáo (artigo 11.\%/3). O SNS presta cuidados de saúde de forma universal e tendencialmente gratuita (artigo 22. ${ }^{\circ}$, já que podem ser cobradas taxas moderadoras, nos termos do artigo $28 .^{\circ}$ ), financiando-se pelo Orçamento Geral do Estado (artigo 27. ${ }^{\circ}$ ), mas cobrando receitas próprias e podendo receber doaçóes.

O seu nível é bipartido, incluindo uma componente Central (Estadual) e Local (Provincial e Municipal) - artigo 17. ${ }^{\circ}$. Identificam-se, no SNS angolano ${ }^{12}$, três níveis de hierarquia (artigo $12^{\circ}$ ): o nível de base é representado pelos Cuidados Primários de Saúde, dispensados pelos postos e centros de saúde, postos de enfermagem e consultórios médicos e hospitais Municipais. Num plano intermédio (secundário)

12 Cristóvão SIMÓES. Transcriçôes da Conferência Final realizada no âmbito do Projeto, retificadas e aprovadas pelo Orador. 
surgem os hospitais gerais. O cume da pirâmide cabe aos hospitais de referência, mono ou polivalentes, diferenciados e especializados.

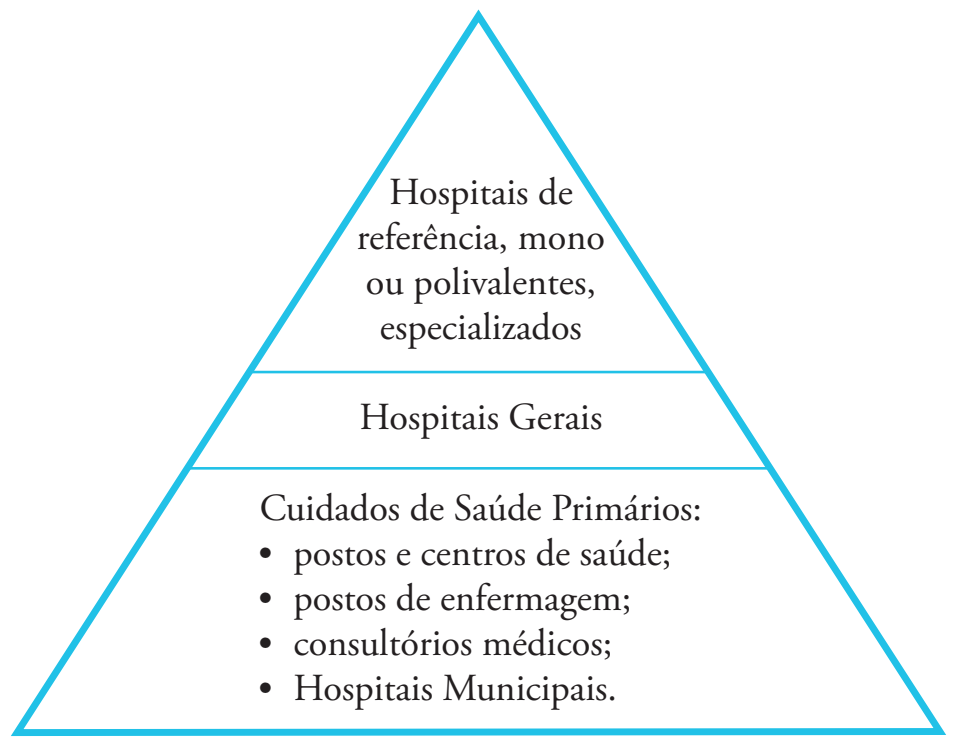

Figura 1 - Hierarquia do SNS em Angola

No Brasil, o diploma estruturante nesta matéria é a Lei n. ${ }^{\circ} 8.080$, de 19 de setembro de 1990, que estabelece o Sistema Único de Saúde (SUS), a qual estabelece que "A iniciativa privada poderá participar do Sistema Único de Saúde (SUS), em caráter complementar" (artigo 4. $\% / \$ 2$ ) e dispondo de um Título (Título II) prevendo a possibilidade de a assistência à saúde ser feita por meio de iniciativa privada e possibilidade de articulaçáa entre o SUS e privados, designadamente por incapacidade de resposta do SUS. O SUS é financiado pelo orçamento da seguridade social (artigo 31. ${ }^{\circ}$ ), dispondo ainda de receitas, por exemplo, de doaçóes e de taxas e emolumentos cobrados pelos seus serviços. Um inquirido explicou que, não obstante a cobertura universal do SUS, "cerca de $25 \%$ da populaçáo possui plano/seguro privado de saúde para as açóes ambulatoriais e hospitalares", valor com alguma expressão, pelo que considera que o sistema é misto.

Em Moçambique, o sistema público de saúde foi instituído pela Lei n. ${ }^{\circ}$ 25/91 de 31 de dezembro, sendo que a articulação com entidades privadas é prevista pela Lei $n .^{\circ} 26 / 91$ de 31 de dezembro (alterada pela Lei n. ${ }^{\circ} 24 / 2009$ de 28 de setembro). Os inquiridos revelam a 
destruturação do sistema público de saúde, não se revendo no incremento da expressividade de seguros privados.

Na RAEM funcionam os Serviços de Saúde de Macau (SSM), dotados de autonomia administrativa, financeira e patrimonial (artigo $1^{\circ} \mathrm{do}$ Decreto-Lei n. ${ }^{\circ}$ 81/99/M, de 15 de novembro). Nos termos do artigo $52 .^{\circ}$ do Decreto, constituem recursos dos SSM dotaçóes inscritas no Orçamento Geral da RAEM, contribuições descontadas aos trabalhadores da Administração Pública para a assistência médica e medicamentosa mas, também, entre outros recursos, as importâncias cobradas pelos serviços prestados. Foi esclarecido por um inquirido que, em Macau, o sistema é de origem Beveridgiano, apresentando cada vez mais um caráter misto, por força da contratação de seguros privados de saúde a nível empresarial, quando, após 1999 , se verificou um decréscimo da qualidade desses serviços, daí que outro inquirido tenha até classificado o sistema de misto. Foi-nos esclarecido também que de acordo com o artigo 123. ${ }^{\circ}$ da Lei Básica, o Governo da Regiáo Administrativa Especial de Macau define, por si próprio, a política respeitante à promoção dos serviços de medicina e saúde.

O papel do terceiro setor (setor social, cooperativo, misericórdias, fundaçóes caritativas) no âmbito da prestação de cuidados de saúde entende-se que devia ser potenciado, em Portugal. O terceiro setor assume um papel importante ${ }^{13}$, por exemplo, ao nível das unidades de cuidados continuados integrados. A presença de "[...] instituições particulares de solidariedade social e de outras de reconhecido interesse público sem carácter lucrativo [...]" está prevista no artigo 63.\%/5 da CRP, recebendo o apoio e fiscalização do Estado, "[...] com vista à prossecução de objetivos de solidariedade social [...]". O mesmo problema enfrenta Angola, país no qual o terceiro setor é quase inexistente, resumindo-se a instituiçõos religiosas (Igreja Católica e Igreja Evangélica Congregacional) que têm hospitais nas suas Missôes que vão prestando algum serviço na prestação de cuidados de saúde. Cristóvão Simôes ${ }^{14}$ assinalou ainda

13 Sobre o assunto, vide: Pedro M. LOPES DE OLIVEIRA. A importância do terceiro setor na prestação de cuidados de saúde: Exemplo da Região Centro de Portugal, Dissertação para obtenção do Grau de Mestre em Gestấo de Unidades de Saúde, Universidade da Beira Interior, Ciências Sociais e Humanas, fevereiro 2013.

14 Cristóvão SIMÕES. Transcrições do Workshop realizado no âmbito do Projeto, subordinado ao Tema: A Pandemia Covid-19 no Espaço da Lusofonia, retificadas e aprovadas pelo Orador. 
um programa de apoio social muito importante chamado "Kwenda", que significa em muitas das línguas nacionais de Angola "viajar”, "andar", "ir", "vir"... Este programa tem agentes de desenvolvimento comunitário e sanitários (ADECOS) cuja missão é registar áreas e pessoas com níveis graves de pobreza e catalogar áreas de risco de contaminação da covid-19. Também se dedicam à educaçáo das pessoas para o uso de medidas pessoais e comunitárias de prevenção da covid-19. No Brasil, a capacidade de resposta do terceiro setor foi potenciada por meio da Lei no 13.995 , de 5 de maio de 2020, a qual prevê a prestação de auxílio financeiro pela Uniāo às santas casas e hospitais filantrópicos, que, sem fins lucrativos, participam no combate à SARS-CoV-2.

$\mathrm{Na}$ RAEM, um inquirido destaca o papel do terceiro setor sobretudo junto dos cidadãos mais carenciados e trabalhadores migrantes.

Dos 30 inquiridos que responderam claramente a esta questão, $65 \%$ entende que o terceiro setor funciona de modo complementar aos sistemas nacionais de saúde. No Brasil, os inquiridos sublinham que este setor permite aliviar a sobrecarga dos sistemas públicos. Na RAEM e Angola, há quem refira que o setor é quase inexistente, muito limitado, mas que, apesar da sua fraca valorização, desempenha um papel preponderante junto dos grupos populacionais mais fragilizados. Esta é uma tendência de resposta comum a outros ordenamentos: $30 \%$ do total de inquiridos reconhece a importância junto de grupos populacionais específicos. Um inquirido de Angola refere, a este respeito, que “ [ ] existem clínicas privadas com limitação de acesso pela maioria da população devido aos altos custos. Por outro lado, existem instituiçóes de carácter caritativo e misericórdias sobretudo vinculadas a instituiçóes religiosas que prestam serviço sem pagamento ou com pagamento pecuniário cujos custos são muito mais baixos se comparados com os serviços prestados por clínicas privadas.".

Avaliando em seguida o grau de preparação para situaçóes de emergência, denota-se que, na grande parte das instituiçóes inquiridas, anteriormente à pandemia da SARS-CoV-2, não existiam mecanismos de preparação e resposta para situaçôes de emergência (por exemplo: teletrabalho, uso de equipamento de proteçấo individual, telemedicina, ensino à distância, limitação de visitas, etc.). Em Angola, apenas dois dos inquiridos respondeu afirmativamente a esta questão: não havia, no geral, implementação destes mecanismos nas instituiçóes. Foi reportado apenas um caso de preparaçáo, tanto em Moçambique como 
na RAEM. A mesma situação de falta de preparação se identificava em Portugal: se olharmos ao caso da Universidade de Coimbra, a instituição a que um número relevante de investigadores da Equipa está afiliado, estes mecanismos não existiam. No Brasil, foram reportados onze casos de instituiçôes que previam já a possibilidade de adoção de trabalho remoto em caso de necessidade, nomeadamente um dos casos para prestação de apoio à família e que será extendido, em breve, para proteção da maternidade (grávidas e mães de crianças até aos dois anos) e para aqueles que têm a seu cargo portadores de deficiência. Em Moçambique, um dos inquiridos referiu que a instituição onde trabalha havia já há muito investido na implementação e melhoria da telemedicina, vendo com bons olhos a imposiçáo de obrigatoriedade destes mecanismos, por agilizarem e flexibilizarem a prestação de cuidados de saúde.

Considerando agora a opiniâo dos inquiridos, quanto à obrigatoriedade destes mecanismos nas instituiçôes ligadas à saúde, quase todos se mostraram favoráveis à sua imposição. Da parte da Equipa, ficou claro que seria benéfico pelo menos a manutenção de stocks de EPI, nomeadamente máscaras cirúrgicas e álcool-gel e equipamentos de medição da temperatura, pelo menos nas instituiçóes ligadas à prestação de cuidados de saúde. Foi reconhecida ainda grande utilidade à organização de simulacros, semelhantes aos que são obrigatórios para terramotos e incêndios, por exemplo, organizando uma situação em que em duas semanas, numa Escola, se adota o ensino à distância, cumprindo protocolos para o efeito preparados. Apenas um inqurido se manifestou contra esta obrigatoriedade, por entender que uma imposição legal náo atenderá ao contexto particular de cada instituição de saúde.

Relativamente a Portugal, um inquirido esclarece que "se faz planeamento de contingência em saúde pública (de âmbito nacional e implementação local) desde 2004 e que em 2007 foi elaborado o plano de contingência nacional para a pandemia de gripe (i.e., dois anos antes da emergência da chamada "gripe A")".

Quanto à existência de uma Instituição Nacional que emite recomendaçôes para atuar em caso de pandemia, em Angola essa função cabe à Direção Nacional de Saúde, um órgáo dentro da estrutura orgânica do Ministério da Saúde. Existe também uma Comissão Interministerial de Combate à Covid-19. 
No Brasil, foi-nos dito que: "[...] historicamente, a coordenação nacional para as pandemias (ao exemplo da AIDS, H1N1) esteve sob a guarida da Secretaria Nacional de Vigilância em Saúde, subordinada ao Ministério da Saúde (União), a partir de comandos debatidos e pactuados em Comissóes Intergestores, sem deixar de considerar as competências específicas da Agência Nacional de Vigilância Sanitária (Anvisa). No ano 2020, durante a pandemia da Covid-19, em face das dificuldades com um discurso uníssono em prol das medidas de prevenção, controle e mitigação da pandemia, provocado, o Supremo Tribunal Federal (Corte Constitucional do Brasil) posicionou-se por reconhecer a competência concorrente dos entes estadual, distrital e municipal para os fins da emissão de recomendaçóes em seus respectivos territórios, sendo assim, a autoridade emitente das recomendaçóes é pertencente ao setor público, em qualquer das esferas.".

Em Portugal essa instituição é a Direção-Geral da Saúde (DGS), que depende do Governo. O Decreto Regulamentar n. ${ }^{\circ}$ 14/2012, de 26 de janeiro aprova a orgânica da DGS enquanto serviço central do Ministério da Saúde (que dispóe não só de receitas provenientes do Orçamento de Estado como também de receitas próprias - artigo 6. ${ }^{\circ}$ ), integrado na administração direta do Estado, dotado de autonomia administrativa (artigo 1. ${ }^{\circ}$ ). Entre as atribuiçôes da DGS está a vigilância epidemiológica de determinantes da saúde e de doenças transmissíveis, assim como a coordenação de sistemas de alerta e resposta apropriada a emergências de saúde pública (artigo 2.\%/2/b)). A emissão de normas e orientações e a colaboração na definição de políticas e prioridades do Ministério Público integram também a missão da DGS (2.o/2/a) e e)). Em 2017, a linha Saúde 24, que assumiu um relevante papel durante a Pandemia, (Centro de Contacto do Serviço Nacional de Saúde - CCSNS), sujeita a uma nova configuração, saiu da competência da DGS para os SPMS - Serviços Partilhados do Ministério da Saúde, E. P. E., (SPMS, E. P. E.), por meio do Decreto-Lei n. ${ }^{\circ}$ 69/2017, de 16 de junho. Um inquirido esclarece a competência do INFARMED também para emitir recomendaçóes.

Em Macau, por meio do Despacho do Chefe do Executivo n. ${ }^{\circ}$ 23/2020, de 21 de janeiro, foi criado o Centro de Coordenaçáo de Contingência do Novo Tipo de Coronavírus (cujo apoio financeiro, administrativo e logístico cabe aos Serviços de Saúde - artigo $6^{\circ}$ - e sob a dependência direta do Chefe do Executivo - artigo 3. ${ }^{\circ}$ ) responsável 
pela planificação global, orientação e coordenação das açóes das entidades públicas e privadas, no âmbito da prevenção, controlo e tratamento das infeçóes pelo novo tipo de coronavírus. Um inquirido salienta ainda o papel da Secretaria para a Saúde e os Assuntos Sociais e Cultura e da Direcção de Serviços de Saúde (SSM), bem como do Centro de Prevenção e Controlo da Doença dos Serviços de Saúde.

Em Moçambique, foi salientado o papel do Decreto Presidencial n. ${ }^{\circ} 41 / 2020$ de 28 de dezembro, através do qual "foram definidas as competências, organização e funcionamento da Entidade Coordenadora de Gestão e Redução do Risco de Desastres, criada por via da Lei n. ${ }^{\circ} 10 / 2020$, de 24 de Agosto, com a designação de Instituto Nacional de Gestáo e Redução do Risco de Desastres. Entre os respectivos órgãos temos o Conselho Técnico de Gestão e Redução do Risco de Desastres, órgão multissectorial de aconselhamento técnico ao Conselho Coordenador de Gestão e Redução do Risco de Desastres sobre matérias de gestão e redução do risco de desastres, presidido pelo Presidente do Instituto e integra os directores e representantes de diversas áreas, incluindo da saúde. Na prossecução dos seus objectivos, compete ao Conselho Técnico de Gestão e Redução do Risco de Desastres, entre outras funçóes: coordenar os sistemas sectoriais de alerta e aviso prévio sobre fenómenos de origem meteorológica, hidrológica, geológica, epidemias, pandemias e impactos na segurança alimentar e nutricional; bem como propor ao Conselho Coordenador de Gestão e Redução do Risco de Desastres a declaração da Situação de Calamidade Pública ou de Emergência.".

Avaliando a resposta à emergência de saúde pública SARS-CoV-2, especificamente no que atem à alocação de recursos públicos no que respeita à prevenção, tratamento e reabilitaçáo dos doentes COVID, os dados presentemente disponíveis relativos a Portugal são os analisados pelo Jornal Público ${ }^{15}$, que apontam como maior gasto do Estado a compra de EPI, ascendendo a 212.743.342 euros. Para além deste equipamento, que visa prevenir a propagação do vírus, a testagem também assumiu uma parte substancial das despesas do Estado, quase 60 milhôes de euros. Um dos contratos com valor mais expressivo foi a aquisição de 243 ventiladores a uma empresa de Cantão, no montante

15 Mapa Interativo disponível em: https://www.publico.pt/interactivo/gastos-covid-19\#/ (último acesso a 13/02/2021). 
de mais de 10 milhóes de euros (de um total de quase 40 milhóes gastos na compra de ventiladores, valor que náo compreende os 4 milhôes despendidos com os acessórios necessários a estes equipamentos). Outros gastos com tratamento incluíram a compra de medicamentos (cerca de 11 milhóes). Não obstante os elevados custos de prevenção contra a SARS-CoV-2, é compreensível que se aposte cada vez mais neste vetor de mitigaçáo da Pandemia. É representativo o elevado custo de manutenção de doentes nos cuidados intensivos, quando os doentes são encaminhados para instituiçóes privadas: o internamento de um doente Covid com tratamento com recurso a ventilador pode custar ao Estado 8431 euros $^{16}$, que os privados entendem ser bastante inferior ao real custo do serviço.

Os inquiridos portugueses estão, no geral, insatisfeitos com a alocação de recursos. Dos 7, 4 avaliam-na como negativa e 3 como razoável (por ter sido feita na medida do possível/disponível). Entende-se que a alocação foi mal feita, com falhas na distribuição, recursos mal geridos, fraco investimento na prevençáo. Especial destaque foi dado por um inquirido quanto às falhas no apoio ao setor social, que dependeu de apoio de privados no fornecimento de EPI e outros equipamentos essenciais.

Em Angola, as opiniōes relativas a esta matéria foram relativamente divididas: por um lado, alguns inquiridos consideraram que essa alocação tem sido feita na medida das disponibilidades do Orçamento do Estado e, neste sentido, tem sido positiva. Por outro lado, consideram que a resposta foi demasiado centralizada, não chegando a todo o território e que a prevenção não recebeu recursos suficientes.

No Brasil, dos 8 inquiridos que responderam à questáo, 6 avaliam negativamente a alocação feita (alocação razoável e positiva receberam, respetivamente, um voto). Defendeu-se a necessidade de serem mobilizados mais recursos e se fazer uma melhor gestão destes. Condenou-se o desvio de verbas públicas, a demora na distribuição de materiais e o investimento em tratamentos comprovadamente ineficazes do ponto de vista científico.

16 Vide, como referência, o Apêndice I do Clausulado tipo para adesão ao Acordo entre as ARS e as entidades privadas para a prestaçáo de cuidados de saúde no âmbito das medidas excecionais e temporárias para tratamento da COVID-19, disponível em: http://www.acss.min-saude.pt/wp-content/uploads/2020/11/Clausulado-Tipo-Convencao-Hospitais-Privados_V_Nov-2020.pdf (último acesso a 13/02/2021). 
Em Moçambique, a alocação de recursos foi classificada, por um inquirido de "péssima". Outro considera que foi feito o que era possível, defendendo que a alocação foi, assim, razoável.

$\mathrm{Na}$ RAEM, em lugar de uma estratégia de mitigação, denota-se a adoção de procedimentos com vista a evitar a entrada do vírus no território, bem como de impedir a sua transmissão comunitária. A alocação de recursos incide, assim, na prevenção da propagação (distribuição organizada de máscaras aos residentes, instalação de equipamentos de medição da temperatura em locais públicos, etc.). Dos 5 inquiridos que responderam à questão, todos estavam satisfeitos com a alocação implementada no território.

Um inquirido testemunhou que "A RAEM adoptou uma estratégia de supressão/eliminação epidémica. A prevenção, tratamento e reabilitação dos doentes COVID-19 tem sido objectivo com elevado grau de prioridade na alocação de recursos públicos (especialmente a prevençáo)".

Atendendo a estes valores e dados, entende a Equipa que a prevenção deve assumir a principal prioridade na alocação dos recursos públicos na saúde na gestấo desta pandemia. Os custos com EPI, informação e campanhas de esclarecimento, embora significativos, permitem controlar o desenvolvimento das fases da Pandemia, evitar infeçóes e mortes. Entre as respostas dos inquiridos, a prevençáo pareceu surgir também como essencial: aumento da capacidade de testagem, disponibilização de informação aos cidadáos, aumento do número de leitos hospitalares e, no geral, investimento no setor da saúde (instalaçóes hospitalares, equipamentos, etc.).

Perante os dados recolhidos, ficou claro para a Equipa que a transmissão de informação relativa à resposta de emergência de saúde pública COVID-19, por parte das autoridades oficiais, tem sido pouco rápida e clara, em Portugal. As autoridades demoraram a aconselhar a utilização de máscaras à população, negaram que o transporte aéreo fosse uma fonte rápida de propagação do vírus, não obstante, em sentido aparentemente contrário, terem referido a necessidade de se arejarem as casas, e nada fizeram, na primeira onda do vírus, relativamente aos transportes públicos, mormente urbanos - um dos locais de maior concentração de pessoas e propício a contágios, sem medidas práticas de distanciamento obrigatório, a não ser, a dada altura, e em contramão, a redução da sua frequência... Mais recentemente, depois de muitos 
países europeus terem abandonado o uso das chamadas "máscaras sociais", por náo oferecerem as necessárias garantias de segurança contra as novas estirpes de SARS-CoV-2 e os Estados Unidos da América recomendarem a utilização de duas máscaras sobrepostas em vez de uma só, as autoridades têm tido dificuldades em rápida e eficazmente esclarecer a população quanto às novidades de prevenção. Disseminada a ideia de que a correta utilização de máscaras poderia ser mais vantajosa do que a adoção das opções propugnadas por outros países, não se assiste a campanhas de informação por via da televisão, por exemplo, explicitando com linguagem e imagética clara e acessível, os cuidados a ter na sua seleção, utilização, manuseamento e descarte. 5 dos 7 inquiridos apontam informaçôes contraditórias, excesso de informação, informação pelo medo, desinformação, etc. Apenas 1 considera que foi positiva. Outro apelida a transmissão de "rápida, mas não clara".

Além disso, enquanto que em Moçambique, por exemplo, foi relatado à Equipa, nas sessóes de partilha realizadas com especialistas, que se privilegiou a mobilização maciça dos meios de comunicaçáo social, Portugal pecou pela falta de informação de clara interpretação, denotando-se que a população foi alvo de divulgaçáo de muitos dados numéricos, estatísticos, de difícil apreensão para o público em geral, ficando particularmente suscetível à desinformação. Dos 4 inquiridos moçambicanos, 3 entendem que a transmissão foi positiva, elogiando o facto de essa ter sido uma grande prioridade política, frisando que os "meios de comunicação social mantiveram o seu normal funcionamento inclusive no decorrer do estado de emergência".

Em Angola, entende-se que a informação tem sido transmitida de forma clara e rápida. Dos 8 inquiridos, apenas um entende que foi negativa. Avaliada como razoável por 2 inquiridos, alerta-se para o facto de os meios de comunicação como a rádio e a televisão não chegarem a toda a população. Houve também um inquirido que considera que há algumas dúvidas sobre a fiabilidade dos números de infeçôes publicitados.

No Brasil, uma das dificuldades inerentes ao combate à SARS-CoV-2 identificadas pelo Professor Doutor Fernando Cupertino ${ }^{17}$, é,

17 Fernando CUPERTINO. Transcrições do Workshop realizado no âmbito do Projeto, subordinado ao Tema: A Pandemia Covid-19 no Espaço da Lusofonia, retificadas e aprovadas pelo Orador. 
precisamente, a inexistência de uma rede de informação eficaz através da comunicaçáo social, designadamente apta a fornecer informaçóes educativas à população. Os inquiridos apontam o dedo ao Governo, que se mostrou ineficiente a divulgar informação de uma forma clara e apreensível, propugnando a adoção de comportamentos cientificamente condenáveis, assim como menosprezando o potencial pandémico da SARS-CoV-2, que dificultou a adoção de medidas eficazes de prevenção da transmissão, como, desde logo, o distanciamento social. Fala-se na inexistência de um "plano de comunicação, nacionalmente coordenado, que possa refletir um pensamento uníssono das autoridades sanitárias.". A opinião dos inquiridos espelha esta opinião: 11 de 15 brasileiros entende que houve divulgação de informaçóes contraditórias, de forma não tempestiva, agravada por ser de difícil apreensão e não ter, muitas vezes, a necessária base científica.

Na RAEM, verificou-se grande mobilização dos meios de comunicação para transmitirem publicidade institucional, alertando a população para a necessidade de adoção de práticas essenciais de etiqueta respiratória, incluindo orientaçôes sobre a correta utilização de máscaras, lavagem das mãos, higienização de espaços, assim como explicitando a forma como os meios de rastreio digital devem ser utilizados. Em outubro de 2020, um estudo da Macao Polling Research Association $^{18}$, que inquiriu meio milhar de residentes, chegou à conclusão que $95 \%$ da população estava satisfeita, em geral, com o desempenho do Governo durante a Pandemia e, em particular, com a forma como as autoridades comunicaram com a população, transmitindo as necessárias recomendaçóes. 5 dos 6 inquiridos avalia a disseminação de informação de forma positiva, com informação clara, complet a e atualizada, identificando-se até, nas palavras de um inquirido, um "excesso de zelo".

Para aliviar os problemas relacionados com a divulgação de informação, foi noticiado, em março de 2021, que o Governo português estava empenhado neste assunto, tendo criado uma Task Force de cientistas para melhorar a comunicação sobre a Pandemia. Da população geral de inquiridos que respondeu à questão (38), as críticas a informações

18 Juliana Qi Xuan YUNCG, , et al., Towards a Dialogic Approach: Crisis Communications and Public Reactions in the World's Most Densely Populated City to Tackle COVID-19, Asian Journal for Public Opinion Research, Volume 8, Issue 3, 2020, pp. 265-296 
contraditórias (26\%), demoradas (13\%) e de difícil apreensão (18\%), foram as prevalentes, pelo que a Equipa recomenda que se empreendam esforços para melhorar estes vetores.

Foi relatado à equipa que, embora não faça parte da experiência de nenhum dos países inquiridos, instituir a figura do mediador de pares (ou similar) pode ser um vetor fundamental para ultrapassar situaçóes semelhantes no futuro. Por estarem próximos das comunidades, os mediadores fazem chegar aos cidadãos informaçóes ajustadas à realidade individual e social, podendo até ocupar-se da realização de inquéritos epidemiológicos e exercendo um papel fundamental no apoio a grupos populacionais fragilizados, fazendo-lhes chegar uma resposta célere e personalizada.

Se se olhar às prioridades nos cuidados de saúde durante a primeira onda da pandemia, denota-se que, em Portugal, o SNS privilegiou ${ }^{19} \mathrm{o}$ combate à Covid ${ }^{20}$, o que significou a quebra do número de consultas, cirurgias e deslocaçóes às urgências hospitalares ${ }^{21}$. $\mathrm{Na}$ segunda onda, procurou-se manter o sistema de saúde, tanto quanto possível, em funcionamento. Não obstante, as cirurgias não emergentes, por exemplo, continuam a ser adiadas, pressionando o já frágil SNS.

No Brasil, detetou-se, num primeiro momento, a alocação de recursos para o combate à Covid, que assumiu um caráter prioritário (aumento do número de leitos hospitalares, direcionamento de certas instituiçóes de saúde para tratamento exclusivo de pacientes Covid, instalação de hospitais de campanha, aquisição de EPI e outros equipamentos essenciais, contratação de mão de obra e suspensão das atividades não essenciais). $\mathrm{Na}$ segunda onda, neste país, os inquiridos

19 O impacto desta opção sobre populações vulneráveis, em particular sobre os doentes respiratórios crónicos, foi avaliado pela Equipa, por meio da contribuição da Professora Doutora Isabel Saraiva, representante da Associação Respira, em Portugal, oradora no Workshop realizado no âmbito do Projeto.

20 De acordo com os dados numéricos obtidos pelo Movimento Saúde em Dia, $57 \%$ dos portugueses consideram que a pandemia dificultou o acesso a cuidados de saúde. Para além disso, registaram-se menos 7,8 milhóes de consultas médicas presenciais nos centros de saúde. Em sentido contrário, os contactos médicos não presenciais duplicaram de 2019 para 2020, passando de 9,1 milhóes para 18,5 milhóes. Vide: https://www.saudeemdia.pt/?p=home (último acesso a 26/02/2021).

21 Com dados numéricos detalhados sobre a estas realidades, cfr: André DIAS PEREIRA e, Ana Elisabete FERREIRA. Vitimas Colaterais da Covid-19, Revista Gestâo Hospitalar, N. ${ }^{\text {20 }}$, jan./fev./mar. 2020, pp. 42-47 
indicam que o esforço assentou na implementação do plano de vacinação e concretização do objetivo de aumentar leitos hospitalares.

Em Angola, os objetivos coincidem com os estabelecidos no Brasil. No entanto, menciona-se também o esforço de capacitação de profissionais (que incluiu a contratação de médicos, designadamente cubanos) e um reforço da capacidade laboratorial. Em Moçambique retrata-se uma realidade semelhante: a mitigação do SARS-CoV-2 recebeu atenção prioritária, preparando-se uma resposta específica para esta Pandemia. Em ambos os territórios, na segunda onda, procurou-se reforçar os meios de resposta. Na RAEM, não foi assinalado, pelos inquiridos, nenhum estabelecimento de prioridades, além da informação à população e adoção de medidas preventivas da transmissão intercomunitária da Covid.

Quanto a alteraçôes na prestação de cuidados de saúde, foram detetadas, por alguns inquiridos, esse tipo de situaçôes. Em Moçambique, um inquirido revela, entre as medidas adotadas: "A criaçáo rápida de uma enfermaria de trânsito para pacientes com covid-19; a abertura de enfermarias provisórias isoladas, para pacientes infectados, em alguns serviços do hospital; uso obrigatório de máscara e viseira pelos profissionais de saúde; uso obrigatório de equipamento de proteção nas enfermarias de trânsito; lavagem obrigatória das mãos em todas as entradas do hospital e respectivos serviços, bem como a aferição da temperatura nas entradas de acesso ao hospital; redução do número de visitas às enfermarias por dia; cancelamento de consultas externas e outros procedimentos médicos não urgentes".

Em Angola, foi também reportado o cancelamento de consultas externas e a suspensão de atividade cirúrgica não urgente. Em Portugal, a reprogramação da atividade hospitalar, em termos semelhantes aos acima descritos, bem como modificações ao nível da tomada de decisão nas instituiçóes de saúde, foram retratadas pelos inquiridos.

No Brasil, um inquirido descreve que foram empreendidos esforços para implementar a telemedicina, reforçando os canais de atendimento náo presencial e capacitando os profissionais para se adaptarem a estes meios digitais.

Relativamente à questão de saber se é desejável que alteraçôes se mantenham após a situação pandémica, os inquiridos mostram-se favoráveis a que permaneçam em vigor algumas delas, nomeadamente o reforço de recursos humanos e materiais e a utilização de EPI. 
Em Macau, não foi identificada qualquer alteração a este nível.

Em Portugal, há situaçôes em que os testes de diagnóstico COVID-19 são gratuitos para o cidadão, que correspondem aos casos em que a testagem é recomendada pelo SNS por suspeita (mobilizados critérios clínicos, epidemiológicos, imagiológicos ou laboratoriais) de infeção por SARS-CoV-2. Já tivemos oportunidade de esclarecer que as seguradoras comparticipam algumas formas de testagem (nem sempre comparticipam as modalidades de testagem TRAg e serológicos), quando a indicação de testagem seja dada pelo SNS. A testagem requerida para efeitos de viagens ou realizada por iniciativa particular, regra geral, não é comparticipada pelas seguradoras. Os preços dos testes particulares (do tipo TAAN) fixam-se em cerca de 100 euros, os serológicos 80 euros e os TRAg cerca de 25 euros. Estes valores são considerados, pelos inquiridos, demasiado elevados e não acessíveis ao cidadão comum.

Em Angola, para pessoas em situação de internamento hospitalar, o teste é gratuito. Se o teste for realizado por via de iniciativa particular, é pago. Entende-se que o custo náo é acessível ao cidadão comum, custando entre 6000 a 75000 kwanzas, segundo um inquirido.

Na RAEM, o teste do tipo TAAN é disponibilizado pelo Governo e por 3 entidades particulares (Hospital Universitário, Hospital Kiang Wu, Namyue Group Macao Federation of Trade Unions). Quando são realizados pelos SSM a residentes da RAEM pela primeira vez, os testes são gratuitos. Depois, custam cerca de 180 patacas. São sempre gratuitos para estudantes, menores de 18 anos, maiores de 65 e portadores de certificados de invalidez. O teste custa 90 patacas quando realizado nas agências particulares, valor acessível à população. Os inquiridos consideram os valores dos testes pagos perfeitamente acessíveis para a população do território.

No Brasil, os inquiridos revelam que, apesar de existirem instâncias nas quais o teste pode ser realizado gratuitamente no quadro do SUS, quando são pagos individualmente pelos cidadãos, estão no mercado por preços muito elevados, inacessíveis à população, rondando o montante de R \$ 270,00 (duzentos e setenta reais). Quadro idêntico vigora em Moçambique: havendo situaçóes em que os testes são gratuitos, a totalidade dos inquiridos reporta que estes não são acessíveis à generalidade da população.

Quanto à rastreabilidade digital, foi implementada em Portugal a aplicação digital StayAway COVID, a descarregar voluntariamente 
pelos cidadãos. Embora o Governo tivesse, em outubro de 2020, empreendido esforços para tornar obrigatório recorrer à aplicaçáo, a votação da Proposta foi abandonada ${ }^{22}$. A aplicação não tinha geolocalização e a sua eficácia foi considerada muito baixa: a inscrição de um caso Covid na aplicação tinha de ser feita por médico e só terão sido enviados 2708 alertas de contágio. Depois de se terem inicialmente identificado cerca de três milhóes de utilizadores, em janeiro de 2021 reportava-se que a Aplicação tinha sido apagada por $60 \%$ dos utilizadores ${ }^{23}$.

Na RAEM, foi implementado o "Código de Saúde de Macau", declaração online através da qual são, obrigatoriamente, fornecidos dados relativos ao estado de saúde antes da entrada no território ${ }^{24}$ (números 1 e 2 do artigo $10 .^{\circ}$ da Lei n. ${ }^{\circ} 2 / 2004$ ), ou, voluntariamente, no território da RAEM, acederem a certos estabelecimentos públicos (Correios, Bancos, Serviços da Função Pública, etc.) ou privados. A utilização da declaração exige a submissão digital de dados pessoais identificativos (nome, data de nascimento, e, mais recentemente, morada do utilizador, etc.), suscetíveis de ser divulgados entre departamentos governamentais e que podem ser processados para rastrear doentes e os seus contactos. Depois da introdução dos dados, estes são processados e é atribuído um Código de cor verde (permissáo de entrada), vermelho (proibição) ou amarelo (necessidade de implementação de medidas de auto-gestáo da saúde). No caso de o interessado náo ser portador de um equipamento móvel, existe a possibilidade de o código digital ser substituído por uma declaração em papel. Em março de 2021, foi noticiado que o Código de Saúde passaria a exibir o registo de vacinação dos residentes a quem já teriam sido administradas as duas doses da vacina. Para além dessa novidade, o sistema digital passou a permitir uma gestáo por zonas, criando registos de áreas afetadas por um eventual surto

22 Proposta de Lei n. ${ }^{\circ}$ 62/XIV, Presidência do Conselho de Ministros, de 14 de outubro de 2020, disponível em: https://app.parlamento.pt/webutils/docs/docath $=6148523063446 \mathrm{f} 764 \mathrm{c} 324679595842774 \mathrm{f} 6 \mathrm{a} 63334 \mathrm{e} 7 \mathrm{a} 63766432$ 6c756157357059326c6864476c3259584d7657456c574c33526c6548 $527663793977634777324 d 693159535659755 a 47396 a \&$ fich $=$ ppl62-XIV.doc $\& I n-$ line=true (último acesso a 13/02/2021).

23 Dados do Jornal Público, 15 de janeiro de 2021

24 Vide, por exemplo, o Despacho do Chefe do Executivo n. ${ }^{\circ}$ 120/2020, de 11 de maio, o qual estabelece entre os requisitos de entrada de trabalhadores náo residentes de Macau que sejam residentes do Interior da China, a necessidade de exibirem o Código de Saúde de Macau verde (artigo 1.\%/3)). 
pandémico e sinalizando os residentes com a cor "vermelha", quando as moradas destes coincidam com a zona afetada.

Já no Brasil, são mais fartas as opçóes de mecanismos de rastreio digital disponíveis. Entre as identificadas pela Equipa, destacam-se: Coronavírus SUS, lançado pelo Ministério da Saúde do Brasil (aplicação móvel digital que, para além de fornecer alertas de contacto, divulga informaçóes oficiais sobre a Pandemia, acedendo à geolocalização do equipamento móvel); Guardióes da Saúde (aplicação móvel digital, desenvolvida pela Associação de Profissionais de Epidemiologia de Campo, associada à Universidade de Brasília, que pretende organizar uma base de dados de notificação de casos leves suspeitos de infeção por SARS-CoV-2, com recurso à geolocalização). A utilização destes mecanismos é voluntária. A primeira aplicação conta com cerca de 10 milhóes de downloads (terceira mais utilizada no Mundo), e a segunda cerca de $19 \mathrm{mil}^{25}$.

Em Angola e Moçambique estes mecanismos não foram adotados. Importa destacar, no entanto, e salvaguardado o facto de não se tratar de um mecanismo de rastreio, a mobilização, em Moçambique, de uma ferramenta digital de Auto-Avaliação de Risco Coronavirus (COVID-19), disponível online, na qual os cidadãos podem submeter certos dados, como a idade e sexo, identificar a presença de sintomas do vírus, bem como fatores de risco (como viagens para locais fortemente afetados).

Avaliando a eficácia destes mecanismos, quando adotados, os inquiridos entendem que a eficácia é "muito pouca" (6 de 12 inquiridos que responderam à questão), apontando a falta de adesão de profissionais de saúde e cidadãos como a razão principal para o insucesso desses mecanismos. Foram também apontados receios relativamente ao processamento de dados pessoais. Um inquirido português defende que "Além de reduzida, a sua eficácia é questionável e até perturbadora da resposta, por parte dos serviços de saúde pública”.

No acesso ao tratamento, há protocolos de atuação, procurando-se, no caso português, evitar o critério do "first come, first served" e privilegiando-se o critério do diagnóstico, sem discriminaçáo de género, idade ou condição social. Em todos os países avaliados, parece claro que têm sido mobilizados os critérios da idade, diagnóstico

25 Dados disponíveis em: https:/www.poder360.com.br/coronavirus/conhecaos-aplicativos-de-rastreamento-da-covid-19-usados-pelos-paises/ (acesso a 04/03/2020). 
(designadamente, refere um inquirido brasileiro, a intensidade da sintomatologia respiratória) e risco (presença de comorbidades).

Relativamente à questão de saber se os profissionais de saúde têm acesso prioritário a diagnóstico e tratamento contra a SARS-CoV-2, foi apontado, por quase todos os inquiridos, a existência destas prioridades (dos 32 inquiridos que responderam a esta questão, 81\% identificam a existência de pelo menos uma forma de prioridade dada aos profissionais), sendo salientado que estes são, designadamente, privilegiados no acesso à vacinação contra a Covid em todos os países/regiáo administrativa avaliados.

Do universo de 37 inquiridos que responderam a esta questão, cerca de $78 \%$ considera real a possibilidade de vir a existir uma outra Pandemia de igual grandeza destruidora, deixando, alguns deles, pendente a resposta quanto às razóes de ser dessa possibilidade, por falta de conhecimento científico sobre o tema. Entre os fundamentos arguidos, destacam-se, com grande prevalência nas respostas dos inquiridos, o histórico recente das Pandemias no contexto mundial, a globalização (e fenómenos associados, como a frequência das viagens internacionais), alteraçôes climáticas (com identificação de agravantes, como destruição de ecossistemas), o aumento da frequência da transmissão de cadeias virais entre animais e humanos (com destaque, pelos inquiridos brasileiros, para a prática de agropecuária intensiva e consumo de carne em grandes proporçôes), a alteração de padrôes de consumo, manipulação laboratorial de vírus e bactérias (e uso prodigalizado de agentes antibacterianos) e possibilidade de guerra biológica. Em Angola, entende-se que a falta de saneamento básico trará implicaçóes ao nível da frequência de propagação de doenças infeto-contagiosas.

Quanto à declaração de Estado de Calamidade/Emergência/Exceção remetemos a explicitação desta realidade para o artigo da Professora Doutora Ana Raquel Moniz. Em todos os territórios avaliados foi suspenso o direito à circulaçáo dentro e para fora do país/região administrativa. Adotou-se, em Portugal, tanto na primeira como na segunda onda, uma política de confinamento domiciliário (dever de permanência no domicílio). Em Angola, este confinamento, de natureza parcial, durou cerca de 30 dias. Foram igualmente suspensos, nos dois países, os direitos de iniciativa privada, social e cooperativa e a requisição civil, embora não se tivesse, até ao momento, materializado, em Portugal, permanece como possibilidade ao dispor do Governo, nos 
temos do Decreto-Lei n. ${ }^{\circ}$ 637/74, de 20 de novembro (ao abrigo do artigo 62.\%/2 da CRP) ou por invocação da Base 34, número 2, alínea d) da Lei de Bases da Saúde a qual prevê a possibilidade de "Proceder à requisição de serviços, estabelecimentos e profissionais de saúde em casos de epidemias graves e outras situaçôes semelhantes", mobilizando "[...] intervenção das entidades privadas, do setor social e de outros serviços e entidades do Estado" (número 3), no caso de emergências de saúde pública. Em Angola, não foi necessário recorrer à requisição civil. Em Macau, a possibilidade de requisição de bens e serviços está também contemplada na Lei n. ${ }^{\circ} 2 / 2014$, no artigo 25. $\%$ /1/10). Neste território, salienta-se que os inquiridos consideram que houve suspensão de direitos fundamentais (reuniáo, manifestaçáo), embora não tivesse havido a declaração de um estado de exceção. Outros falam na restrição (mas não suspensão) de direitos fundamentais, como a liberdade de circulação.

Em Moçambique, não foi adotado um confinamento propriamente dito, decidindo-se pela imposiçáo de redução de acesso a espaços públicos, suspensão do ensino presencial, imposição de recolher obrigatório (designadamente, em Maputo), introdução de trabalho em regime de rotatividade, encerramento de restaurantes, entre outras medidas limitativas também de eventos privados (Decreto n. ${ }^{\circ} 12 / 2020$, de 2 de abril). Destaca-se, desde logo, o Decreto Presidencial n. ${ }^{o}$ 11/2020, de 30 de março, que procedeu à declaração do Estado de Emergência, por razóes de calamidade pública, prorrogado diversas vezes e o Decreto n. ${ }^{\circ}$ 79/2020, de 4 de setembro, que Declara a Situação de Calamidade Pública e Ativa o Alerta Vermelho.

$\mathrm{Na}$ RAEM, o acesso a espaços públicos (nomeadamente casinos, teatros, ginásios, cinemas, etc.) foi limitado por meio do Despacho do Chefe do Executivo n. ${ }^{\circ}$ 27/2020, de 4 de fevereiro. O acesso aos casinos foi retomado a 20 de fevereiro de 2020 e aos restantes espaços públicos a 2 de março do mesmo ano. Restriçóes foram impostas quanto à entrada no território (por exemplo, vide Despacho do Chefe do Executivo n. ${ }^{\circ}$ 40/2020, que entrou em vigor a 20 de fevereiro, estabelecendo, inclusive, períodos obrigatórios de observação médica antes de concretizar a entrada na RAEM). Através do Despacho do Chefe do Executivo n. ${ }^{\circ} 72 / 2020$ (que entrou e vigor a 18 de março), foi proibida a entrada no território de todos os náo residentes e o Despacho do Chefe do Executivo n. ${ }^{\circ}$ 80/2020 suspendeu todos os serviços de 
transferência do Aeroporto Internacional de Macau (artigo 1.\%/2)). As limitaçóes à circulação derivam dos artigos $100^{\circ}, 14 .^{\circ}$ e $15 .^{\circ}$ da Lei n. ${ }^{\circ} 2 / 2014$. Sublinha-se ainda a imposição de quarentena obrigatória de 21 dias, na chegada ao território, num local designado pelas Autoridades e despesas inerentes a cargo do interessado.

As Forças Armadas portuguesas desempenharam um importante papel no rastreio das infeçóes, tendo montado Hospitais de campanha nas suas instalaçốes, recebido doentes nos seus Hospitais (em janeiro de 2021, já teriam sido aí alojados mais de mil infetados por SARS-CoV-2), destacando-se ainda o contributo do laboratório militar no processamento de testes. Em março de 2021, o Decreto n. ${ }^{\circ} 4 / 2021$, regulando a prorrogação do estado de emergência, estatui, especificamente, no seu artigo $14 .^{\circ}$ que as forças armadas se ocupariam da realização de inquéritos epidemiológicos e rastreio de contactos de doentes com COVID-19. Os inquiridos identificaram como uma das tarefas desempenhadas pelas forças armadas o desenvolvimento e implementação do plano de vacinação, embora nem todos vejam com bons olhos a assumção dessa tarefa pelos militares. Foi sugerido que estes desempenhassem um papel mais ativo na organização logística prática do combate à Covid (gestão de equipamentos, apoio à administração e organização de centros de vacinação, que é realizada, designadamente, por forças policiais). Além disso, foi criticado o subaproveitamento do potencial de recursos humanos das forças armadas, assim como a decisão tardia de as incorporar na resposta à Pandemia.

Em Angola, destaca-se o papel desempenhado pelos militares náo só a reforçar a defesa e segurança (controlo de fronteiras), mas também, especificamente, na área da Saúde, com relevantes tarefas na área de testagem e tratamento de pacientes. Em Moçambique, os inquiridos entendem que as principais funçóes assumidas foram a fiscalização das medidas restritivas impostas no decorrer do último ano.

Neste contexto, é importante referir os procedimentos de rastreio que, de acordo com os especialistas ouvidos nas oportunidades de partilha realizadas no âmbito do Projeto, têm sido de grande relevância no combate à Pandemia. No Brasil, a função de rastreio é um papel relevante dos agentes comunitários de família, que integram as equipas de Saúde da Família. São eles o elemento de ligação entre as comunidades e os cuidados de saúde primários, em que também se inclui o rastreio de enfermidades e acompanhamento das condiçóes 
crónicas $^{26}$. Em Moçambique, destaca-se a figura do agente comunitário de saúde: estes profissionais ocuparam-se do rastreio da Covid durante o ano de 2020, estando particularmente próximos das populações.

No Brasil, o papel das forças armadas, para além das funções de rastreio e controlo de contactos e, em geral, de apoio à prestação de cuidados de saúde, foi reconhecido por alguns inquiridos como importante na instalação de hospitais de campanha, distribuição de equipamento hospitalar e, em menor escala, produção da controversa hidrocloroquina.

Houve, em Portugal, significativas alteraçôes aos rituais religiosos. Em 2020, o Decreto n. ${ }^{\circ}$ 14-A/2020, de 18 de março, referia que o exercício de alguns direitos ficava "parcialmente suspenso", entre eles a "liberdade de culto, na sua dimensão coletiva" (artigo 4.o/f)). Embora ao longo do mesmo ano os locais de culto tivessem o acesso limitado por necessidade de fixação de um número máximo de presentes, em 2021, o Decreto do Presidente da República n. ${ }^{\circ}$ 6-B/2021 não previa a mesma suspensão parcial da liberdade de culto (artigo 35\%/1/a) - cerimónias religiosas como exceção à proibição de realização de eventos). A opção de suspender a celebração, designadamente, de Eucaristias públicas, foi tomada pela Conferência Episcopal Portuguesa e vigora desde 23 de janeiro de 2021. Com a imposição de dever de recolhimento domiciliário, as deslocaçóes para participação em cerimónias religiosas mantiveram-se autorizadas (artigo 4. ${ }^{\circ} / 2 / \mathrm{k}$ ) do Decreto n. ${ }^{\circ} 3-\mathrm{C} / 2021$, de 22 de janeiro).

Foram registadas alteraçôes em Angola. Em Moçambique, detetou-se o encerramento de lugares de culto, conferência e reunióes religiosas (artigo 15. ${ }^{\circ}$, Decreto n. ${ }^{\circ}$ 12/2020, de 2 de abril). Na RAEM, as celebraçóes religiosas também estiveram suspensas, medida tomada ao abrigo do artigo 25.\%/1/1) da Lei n. ${ }^{\circ}$ 2/2014.

No Brasil, a questão tem de ser avaliada concretamente em cada Estado e tem gerado alguma polémica. Em sentido contrário à autorização de celebração de atividades religiosas presenciais está, por exemplo, a decisão do Tribunal de Justiça do Estado de São Paulo ${ }^{27}$, de março

26 Fernando CUPERTINO. Transcrições do Workshop realizado no âmbito do Projeto, subordinado ao Tema: A Pandemia Covid-19 no Espaço da Lusofonia, retificadas e aprovadas pelo Orador.

27 Tribunal de Justiça do Estado de São Paulo, Ação Civil Pública Cível, Processo Digital no: 1015344-44.2020.8.26.0053, Relator: Randolfo Ferraz de Campos, 
de 2020, da responsabilidade do Juiz Randolfo Ferraz de Campos, a qual estabelece a proibição "de realização de missas, cultos ou quaisquer atos religiosos" sob "[...] pena de multa diária no valor de $\mathrm{R} \$$ 10.000,00 para cada réu.”. Dias depois, a decisão da Primeira Instância, que dera origem a este recurso, foi revogada pelo Presidente do Tribunal de Justiça do Estado de São Paulo. Outras decisóes judiciais no sentido da suspensão do direito de culto foram determinadas nos tribunais do Rio de Janeiro e Porto Alegre. A 25 de março de 2020, o Decreto n. ${ }^{\circ} 10.292 / 20$ passou a definir as atividades religiosas como atividades essenciais, suscetiveís de serem celebradas respeitando os limites e orientaçôes estabelecidos pelo Ministério da Saúde. Os inquiridos reportam, sobretudo, a fixação de uma capacidade máxima de ocupação dos lugares de culto.

Quanto a rituais fúnebres, em Portugal, depois das dificuldades na determinação de critérios de participação nestes rituais (não discriminação de critérios nos casos de funerais de pessoas infetadas com Covid ou não, fixação de números máximos de pessoas e de horas de duração de velórios, num verdadeiro clima de "desumanização da morte"28), o Decreto n. ${ }^{o}$ 3-A/2021 deixa ao critério das autarquias a definição de medidas organizacionais que garantam a inexistência de aglomerados de pessoas e o controlo das distâncias de segurança, prevendo a possibilidade de fixação de números máximos de presenças, salvaguardando a presença de cônjuge ou unido de facto, ascendentes, descendentes, parentes ou afins (artigo 29. ${ }^{\circ}$ ). Detetou-se nos inquiridos portugueses que este aspeto é alvo de muitas críticas: a privaçáo dos familiares se despedirem de doentes hospitalizados e os rituais fúnebres realizados com muitas limitaçóes são apelidados de uma grande "violência" para familiares dos falecidos.

Foram registadas alteraçôes em Angola. Embora a Lei n. ${ }^{\circ}$ 2/14, através do seu artigo $22 .^{\circ}$ preveja medidas especificas de tratamento de cadáveres em contexto de epidemias e doenças infetocontagiosas, náo se tendo verificado qualquer morte por SARS-CoV-19 em Macau, não houve necessidade de implementar essas medidas adicionais. Em

20/03/2020, disponível em: https://www.defensoria.sp.def.br/dpesp/Repositorio/31/ Documentos/Decisao\%20Liminar\%20do\%20TJSP\%20para\%20suspensao $\% 20$ de $\% 20$ cultos $\% 20$ e $\% 20$ missas $\% 20$ pdf.pdf

28 Cfr, André DIAS PEREIRA e, Ana Elisabete FERREIRA. Vitimas Colaterais da Covid-19... 
março de 2020, com o Festival do Ching Ming (culto dos antepassados), os SSM fizeram chegar aos residentes algumas recomendaçôes ${ }^{29}$ destinadas a evitar a propagaçáo do vírus em cemitérios e sepulcros.

Em Moçambique, o artigo 16. ${ }^{\circ}$ do Decreto n. ${ }^{\circ}$ 12/2020, de 2 de abril determinou que número de participantes na realização de cerimónias fúnebres não deve exceder 20 pessoas, assegurado ainda o cumprimento do distanciamento social e sendo obrigatório o uso de máscara. Regime distinto vale para as cerimónias fúnebres de pessoas que padeciam de COVID-19, nas quais o número de participantes não deve exceder 10 pessoas.

O impacto das alteraçôes de rituais religiosos e fúnebres em Portugal, Angola, Moçambique e Brasil é notório. Nestes países, todos os inquiridos que responderam à questão, detetaram alteraçóes substanciais neste aspeto.

Houve ainda uma limitação ao direito de visita a doentes hospitalizados, abrangendo tanto doentes Covid como não-Covid, nas duas fases da Pandemia, em Portugal, sendo que os inquiridos reportam, inclusive, o desacompanhamento de doentes (invisuais e com mobilidade reduzida) em consultas externas e triagens das urgências. A proibição de visitas, relatam os inquiridos, afetou particularmente os doentes internados por período prolongado nos cuidados intensivos e os pacientes institucionalizados. Um inquirido relatou que essa limitação se aplicou "a todos os doentes. As normas e medidas excecionais foram sendo adaptadas pelos conselhos de administração dos hospitais, centros hospitalares e unidades locais de saúde. Foram, no entanto, fornecidos meios técnicos, em vários hospitais, para que o contacto pudesse ser feito através de videoconferência. Nalguns casos até aproximou mais os doentes dos seus familiares.".

No Brasil, foi salientado pelos inquiridos que as grávidas não puderam ser acompanhadas nos partos. A opção das autoridades angolanas foi distinta, optando por excluir o direito de visita a doentes Covid, mantendo, embora com restriçóes, o direito de visita a doentes não-Covid. Em Moçambique, o Decreto n. ${ }^{\circ}$ 12/2020, de 2 de abril, por meio do seu artigo $4 .^{\circ}$, interditou as visitas a doentes Covid,

29 Prevenção da pneumonia causada pelo novo tipo de coronavirus (COVID-19) - Orientaçóes para prestar homenagem ritual aos antepassados, SSM, 23/12/2020, documento disponível em: https://www.ssm.gov.mo/docs/17723/17723_6c70c78a49c241d492540bcf0828c6ae_000.pdf (Último acesso a 03/03/2021). 
reduzindo-se a frequência das visitas aos outros doentes (máximo de duas pessoas por dia, por cada doente). Em Macau, foram detetadas alteraçóes, embora não tenha ficado claro para os inquiridos a que nível foram introduzidas e quem afetaram.

No que diz respeito ao ensino, ao nível do ensino infantil e juvenil (até aos 18 anos), em Portugal, houve alteração nas práticas educacionais, suspendendo-se todas as atividades letivas presenciais. Nenhum nível de ensino se manteve em regime presencial, tanto na primeira onda como na segunda - desde 5 de fevereiro de 2021 (artigo 3\%/2 do Decreto n. 3-D/2021, de 29 de janeiro). Em Angola, no decorrer do Estado de Emergência, todas as instituiçóes de ensino encerraram (Decreto Executivo n. ${ }^{\circ}$ 124/20 de 30 de março, do Ministério da Educação). Posteriormente, no Estado de Calamidade, introduziu-se um regime presencial limitado no ensino superior e médio.

No Brasil, o ensino assumiu a modalidade não presencial (Portaria no 343, de 17 de março de 2020). Em geral, resulta dos questionários que têm sido causados danos terríveis no sistema educativo. Um inquirido testemunha que: "Ao nível do ensino infantil e juvenil (até aos 18 anos) houve alteração nas práticas educacionais/educativas. A educação infantil e fundamental passou longos meses com vedação de aulas presenciais. A rede pública não foi adaptada para o ensino a distância $\mathrm{e}$ não há previsão de retorno das aulas presenciais. Na rede privada, houve período de retomada das aulas presenciais, mas na 2a. Onda foram novamente suspensas. $\mathrm{O}$ ensino médio foi duramente penalizado, sem aulas presenciais há mais de 11 meses e sem previsão de retorno nem na rede pública e nem na rede privada. O ensino universitário também não tem previsão de retorno às atividades presenciais passados mais de 11 meses do início da pandemia."

Em Moçambique também se identificaram substanciais alteraçôes (Decreto n. ${ }^{\circ}$ 12/2020, de 2 de abril), tendo sido suspenso o ensino presencial. A Professora Orquídea Massarongo ${ }^{30}$, oradora no Workshop realizado no âmbito do Projeto, reporta que o acesso a aulas online, sobretudo nas escolas de ensino público, não dispunha de condiçóes para o realizar: mesmo estudantes universitários têm acesso limitado a

30 Orquídea MASSARONGO. Transcriçôes do Workshop realizado no âmbito do Projeto, subordinado ao Tema: A Pandemia Covid-19 no Espaço da Lusofonia, retificadas e aprovadas pela Oradora. 
computadores e internet, fora das cidades. Com o retomar do ensino presencial, em setembro de 2020, denotou-se que as escolas do ensino público não estavam preparadas para funcionar no cenário da Pandemia que exige, entre outras coisas, higienização regular: em muitas das instituiçốes de ensino náo havia sequer acesso a água, a garantia mais básica para higienização das mãos.

$\mathrm{Na}$ RAEM, os estabelecimentos de todos os níveis de ensino estiveram encerrados nos primeiros meses de 2020, tendo sido introduzidas aulas à distância, online. A reintrodução do regime presencial foi feita faseadamente: as aulas do $4 .^{\circ}$ ao $6 .^{\circ}$ ano reiniciaram no dia 25 de maio; as do $1 .^{\circ}$ ao $3 .^{\circ}$ no dia 1 de junho. Os ensinos infantil, especial, secundário e superior retomaram o seu normal funcionamento depois.

Assim, em todos os países e regiáo administrativa estudados, reporta-se que, pelo menos a um determinado ponto do combate à Pandemia, houve uma suspensão do ensino presencial em todos os níveis de ensino.

Para apoiar o sistema educativo infantil e juvenil, a Equipa propóe a adoção de medidas para potenciar o acesso da comunidade educativa a computadores e internet. Propóe-se ainda um plano de reabertura de escolas de proximidade nas áreas do território em que possa existir um número reduzido de crianças por turma/escola, atendendo-se ainda, no encerramento das escolas, à avaliação casuística do número de alunos e dimensão da escola. A Pandemia da SARS-CoV-2 demonstrou ainda a urgência de se reavaliar a atual dimensão das escolas em Portugal, que embora não tenham sido identificadas nesta específica Pandemia como fonte de propagaçáo do vírus, por esta estirpe, em concreto, não afetar particularmente as crianças, sabe-se que outros vírus epidémicos como a estirpe de H1N1 de 2009-2010, podem vitimizar sobretudo jovens.

Entre as medidas propostas pelos inquiridos, ficou clara a necessidade de disponibilização de equipamentos e planos sociais de internet aos estudantes, adoção de ensino combinando as modalidades presencial e não presencial, apoio psicológico, social e financeiro às famílias, manutenção da atividade desportiva, capacitação dos professores para utilização de equipamentos tecnológicos, transmissão de aulas em canal aberto na televisão (proposta pelos inquiridos de Moçambique e Brasil). Referiu-se ainda a necessidade de restruturação, em geral, dos sistemas de educação, para abranger a preparação para situaçóes pandémicas e equiparadas. 
Em Portugal, estudos sobre a saúde mental das crianças e jovens ganharam particular relevância em 2021, com as perspetivas de agravamento da Pandemia e da aferição do impacto de nova suspensão de atividades letivas presenciais na saúde mental deste grupo populacional. A Equipa salienta os realizados pelo Centro de Estudos e Sondagens de Opiniâo (Cesop) da Universidade Católica para o Público e para a RTP, pela Mind - Instituto de Psicologia Clínica e Forense e ainda "Crise Económica, Pobreza e Desigualdades - Relatório sobre Impacto Socioeconómico e Saúde Mental”, publicado pela Ordem dos Psicólogos Portugueses. Muito recentemente tem grande interesse nesta matéria um Estudo intitulado "O Impacto do Confinamento na Academia de Coimbra”, promovido pela Associação Académica de Coimbra (AAC) e no qual transparecem as insuficiências do ensino à distância e o impacto na saúde mental trazido pelas restrições impostas com a Pandemia ${ }^{31}$. Em Angola, Moçambique e na RAEM, os inquiridos desconhecem, em geral, qualquer estudo nesta matéria.

No Brasil, destacam-se 3 estudos organizados pelo Instituto de Pesquisa Econômica Aplicada (Ipea) e a Organizaçáo Internacional do Trabalho (OIT), centrados em averiguar o impacto da Pandemia no mercado de trabalho jovem, que destacam o aumento da inatividade, não integração da força de trabalho do país e diminuição da capacitação profissional $^{32}$.

Relativamente à população idosa, em Portugal, poucas ou nenhumas medidas foram institucionalmente adotadas para apoiar este grupo populacional. Em Angola, não há registo de medidas adotadas nesta matéria, à exceção de fomento do isolamento deste grupo populacional e fornecimento de EPI aos lares. Os principais apoios, em Portugal, derivaram do terceiro setor e privados e, ocasionalmente, por autoridades municipais, verificando-se situaçóes de abandono ou isolamento. Entre as realidades que mais afetaram esta população, identificam-se, em particular, o encerramento de Centros de Dia - que, para além de privar os idosos da necessária estimulação e interação social, pressionou mais

31 Jornal Público, 12/02/2021, https://www.publico.pt/2021/02/12/p3/noticia/ confinados-74-alunos-universidade-coimbra-pensaram-desistir-estudar-1950408 (último acesso a 18/02/2021).

32 Mais especificamente sobre a temática da Saúde jovem, cfr. Diene M. CARLOS et al., A saúde do adolescente em tempos da COVID-19: scoping review, Cadernos de Saúde Pública, 36 (8) 28 agosto 2020 
cuidadores e famílias - e a proibição de visitas a lares de idosos e hospitais. Salienta-se que, em Portugal, a população residente em lares contribuiu para o grande número de infeçôes e mortes: à avançada idade somava-se a circunstância de serem um grupo de risco pela presença frequente de comorbidades associadas e a residência em espaços fechados. $\mathrm{O}$ isolamento já habitual dos idosos agravou-se com a suspensão de visitas a lares e hospitais e a taxa de mortalidade em lares mantém-se alta pela resistência em adotar sistemas de testagem e regimes de exclusividade dos funcionários destas instituiçóes, com internamento rotativo por equipas, opção que tem sido útil noutros países da Europa ${ }^{33}$. No entanto, um inquirido revela algumas medidas que foram adotadas em lares e que permitiram suavizar o impacto do SARS-CoV-2 nesta população: reforço dos contactos da população idosa à distância, com as famílias e reforço de outras formas de visitas de familiares nas instituiçôes, sem contacto direto, designadamente através de estruturas (como vidros de janelas) transparentes.

Em Moçambique, um inquirido revela o conteúdo do artigo $6 .^{\circ}$ do Decreto n. ${ }^{\circ}$ 26/2020, de 8 de Maio, o qual sujeita a uma "proteção especial" os cidadãos de idade superior a 60 anos, concedendo-lhes uma "prioridade na dispensa da actividade laboral presencial" (número 2 do mesmo artigo) quando o vínculo laboral do cidadão o obrigaria a exercer funçóes presencialmente no decorrer do estado de emergência.

A vacinaçáo prioritária dos idosos é considerada, por grande parte dos inquiridos, a principal (e por vezes única) medida implementada para apoiar esta faixa etária.

O principal Estudo que decorre em Portugal em matéria de avaliação de impacto da SARS-CoV-2 na saúde mental dos idosos é o que está a ser realizado por especialistas do Centro de Investigação em Neuropsicologia e Intervenção Cognitivo-Comportamental da Universidade de Coimbra, por meio do grupo CuidadosaMente ${ }^{34}$.

No que diz respeito ao Acesso ao Medicamento e Ensaios Clínicos de Medicamentos e Vacinas, quanto à existência de ensaios clínicos de

33 André DIAS PEREIRA e Heloísa SANTOS. Reflexóes Éticas e Normativas a Propósito do Artigo: "Direitos Humanos e Mortes Evitáveis", Revista Gestão Hospitalar, N. ${ }^{\circ}$ 21, abril/maio/junho, 2020, pp. 70-76

34 Detalhes do Projeto disponíveis em: https://www.cuidaidosamente.pt/ (último acesso a 14/02/2021). 
vacinas ou de medicamentos para a COVID-19, em Portugal ${ }^{35}$, é de salientar um medicamento experimental à base de células estaminais produzido pela Crioestaminal, empresa de Coimbra, bem como a participação de centros de investigação portugueses nos ensaios clínicos do projeto "Solidarity" da OMS, destinado a recolher dados científicos sobre algumas opçôes de tratamento da SARS-CoV-2. Quanto a vacinas, reportam-se $\mathrm{s}^{36}$ os casos de duas equipas portuguesas que se propuseram avançar com ensaios pré-clínicos no início de 2021 e realizar ensaios clínicos com humanos ao longo do corrente ano. A Equipa é sensível à importância que a genética revelou neste âmbito, permitindo a formulaçáo, em tempo recorde, de vacinas e tratamentos, bem como a identificação e caracterização de novas variantes do vírus. Para além disso, com a interação fortalecida entre genética e Saúde Pública, prevê-se que o direito assuma cada vez mais um papel de destaque nestas questôes, pelo que se recomenda uma especial atençáo aos casos de cedência e venda a terceiros de informaçóes genómicas por agências de investigação ${ }^{37}$.

No Brasil, identificam-se, neste momento, cerca de 20 vacinas em fase preliminar, que não deverão estar disponíveis em 2021. Alguns destes projetos científicos são financiados pelo Governo. Não há registos, em Angola, Moçambique e na RAEM de ensaios clínicos de vacinas ou medicamentos.

No que atem a incentivos a participar em estudos clínicos relativos à COVID-19 nas instituiçóes onde os inquiridos exercem a sua atividade profissional, no universo de inquiridos, há apenas registo de 5 casos em que essa participação foi fomentada (2 no Brasil, 2 em Angola e 1 em Portugal).

35 Atendendo à situação de Pandemia, o INFARMED publicou Medidas excecionais no âmbito da realização de Ensaios Clinicos, durante o periodo de risco para a saúde pública, as quais podem ser consultadas em: https://www.infarmed.pt/documents/15786/3584301/Medidas+excecionais+no+ambito+da+realizacao+de+Ensaios+C IInicos\%2C+durante+o+perIodo+de+risco+para+a+saude+publica/60c07e97-6bb9-a972-df05-20fba160e82d (último acesso a 14/02/2021).

36 Jornal Público, 3/02/2021: https://www.publico.pt/2021/02/03/ciencia/noticia/vacinas-portuguesas-covid19-procuram-dinheiro-testes-humanos-1949013 (último acesso a 14/02/2021).

37 Heloísa SANTOS, A evolução no campo da genética tem sido essencial no combate à pandemia, entrevista dada à Gradiva Publicaçóes. 
O uso off-label (fora da indicação terapêutica prevista na AIM Autorização de Introduçáo no Mercado) de medicamentos no tratamento da COVID-19 é aceite em Portugal: foram reportados casos de utilização de esteroides como a dexametasona, assim como de medicamentos antivirais usados no tratamento de VIH, e a DGS autorizou especificamente o uso de medicamentos prescritos normalmente para o tratamento da malária e ébola. Um inquirido afirmou: "Náo já que no contexto da COVID-19 náo existiu nenhuma evidencia cientifica sólida para sustentar a sua utilização. Existiram ensaios mas foram inconclusivos e demonstraram que não há mais-valias.”.

No Brasil, a população inquirida explica que esta foi uma opção política do Governo, muitas vezes sem comprovação científica a suportar esse uso off-label, sendo tendencialmente mal vista pelos inquiridos, estando em vigor a Orientação do Ministério da Saúde para Manuseio Medicamentoso no Tratamento da COVID 19, que prevê essa utilização. Para os inquiridos dos restantes territórios, a resposta a esta questão não é muito clara.

Em todos os territórios estudados existe um plano nacional de vacinação da população contra a Sars-Cov-2. Há grupos prioritários estabelecidos nestes planos. $\mathrm{O}$ acesso à vacina será gratuito para todos os nacionais/residentes desses países/região.

Em Portugal, Angola e na RAEM a vacinação é voluntária. Quanto à possibilidade de exigência de vacinação como requisito de entrada em Portugal, a apresentação pela Comissão Europeia, no passado dia 17 de março, de um Regulamento com vista à adoção de um Certificado Verde Europeu trará novidades nessa matéria ${ }^{38}$. No Brasil, o Acórdão do Supremo Tribunal Federal no julgamento conjunto das Açóes Diretas de Inconstitucionalidade dos Processos n. ${ }^{\text {os }}$ ADI 6586 e 6587 e do Recurso Extraordinário com Agravo do Processo n. ${ }^{\circ}$ 1267879, afirma a possibilidade de vacinação compulsória dos cidadáos, no superior interesse da saúde pública. Ainda quanto a este aspeto, alguns inquiridos detetam, nos diferentes territórios, que está em estudo a possibilidade de esta vacinação ser obrigatória para certas profissóes ou para ser autorizada a entrada no respetivo país/região administrativa.

38 Disponível, em inglês, em: https://ec.europa.eu/info/files/proposal-regulation-interoperable-certificates-vaccination-testing-and-recovery-digital-green-certificate_ en (último acesso a 19/03/2021) 
Figura 2 - Quadro Comparativo dos Planos de Vacinação

\begin{tabular}{|c|c|c|c|c|c|}
\hline & Angola & Brasil & Moçambique & Portugal & RAEM \\
\hline Base Legal & & $\begin{array}{l}\text { Medida provisó- } \\
\text { ria n. }{ }^{\circ} 1.026, \text { de } \\
6 \text { de janeiro de } \\
2021\end{array}$ & & $\begin{array}{c}\text { Portaria } \\
\text { n. }{ }^{2} 298-\mathrm{B} / 2020\end{array}$ & $\begin{array}{c}\text { Despacho } \\
\text { do Chefe do } \\
\text { Executivo } \\
\text { n. } 27 / 2021\end{array}$ \\
\hline $\begin{array}{c}\text { Data da } \\
\text { Primeira } \\
\text { Inoculaçắo }\end{array}$ & $02 / 03 / 2021$ & $17 / 01 / 2021$ & $08 / 03 / 2021$ & $27 / 12 / 2020$ & $09 / 02 / 2021$ \\
\hline 1. ${ }^{a}$ Fase & $\begin{array}{l}0 \text { 2 } / 2 \text { l } 20 \text { l } 2 \text { l } \\
06 / 2021 \\
\text { - Profissionais de } \\
\text { saúde, serviços } \\
\text { sociais e da or- } \\
\text { dem e segurança } \\
\text { pública; } \\
\text { - Pessoas com } \\
\text { morbilidades de } \\
\text { risco; } \\
\text { - Pessoas de } \\
\text { idade igual ou } \\
\text { superior a } 40 \\
\text { anos (entre estas, } \\
\text { priorizando as de } \\
\text { idade superior a } \\
65 \text { anos e as com } \\
\text { maior probabili- } \\
\text { dade de exposi- } \\
\text { ção ao vírus). }\end{array}$ & $\begin{array}{l}\text { 01/2021 } \\
4 \text { Subfases } \\
\text { PRIMEIRA: } \\
\text { - Trabalhadores } \\
\text { de Saúde; } \\
\text { - Pessoas de } 75 \\
\text { anos ou mais; } \\
\text { - Pessoas de } 60 \\
\text { ou mais anos, } \\
\text { institucionaliza- } \\
\text { das; } \\
\text { - Populaçáo in- } \\
\text { dígena em terras } \\
\text { demarcadas; } \\
\text { - Povos e comu- } \\
\text { nidades tradicio- } \\
\text { nais ribeirinhas; } \\
\text { SEGUNDA: } \\
\text { - Pessoas de } 60 \text { a } \\
\text { 74 anos (priori- } \\
\text { zadas por grupos } \\
\text { de idades); } \\
\text { TERCEIRA: } \\
\text { - Pessoas com } \\
\text { idade igual ou } \\
\text { superior a 18 } \\
\text { anos portadoras } \\
\text { de uma das mor- } \\
\text { bidades previstas } \\
\text { no plano; } \\
\text { QUARTA: } \\
\text { - Professores do } \\
\text { ensino básico ao } \\
\text { superior; } \\
\text { - Forças de se- } \\
\text { gurança e salva- } \\
\text { mento; } \\
\text { - Funcionários } \\
\text { do Serviço Pri- } \\
\text { sional. }\end{array}$ & $\begin{array}{l}\text { - Profissionais de } \\
\text { saúde; } \\
\text { - Idosos que } \\
\text { vivem em lares } \\
\text { e auxiliares que } \\
\text { trabalhem nestas } \\
\text { instituiçóes; } \\
\text { - Forças de De- } \\
\text { fesa e Segurança; } \\
\text { - Pacientes com } \\
\text { diabetes Mellitus }\end{array}$ & $\begin{array}{l}\text { 3 Subfases } \\
\text { PRIMEIRA: } \\
\text { 12/2020 } \\
\text { - Profissionais de } \\
\text { saúde envolvidos } \\
\text { na prestaçâo de } \\
\text { cuidados a doen- } \\
\text { tes; } \\
\text { - Profissionais } \\
\text { das forças arma- } \\
\text { das, forças de } \\
\text { segurança e servi- } \\
\text { ços críticos; } \\
\text { - Profissionais e } \\
\text { residentes em Es- } \\
\text { truturas Residen- } \\
\text { ciais para Pessoas } \\
\text { Idosas e institui- } \\
\text { çóes similares; } \\
\text { - Profissionais e } \\
\text { utentes da Rede } \\
\text { Nacional de Cui- } \\
\text { dados Continua- } \\
\text { dos Integrados } \\
\text { SEGUNDA: } \\
\text { 02/2021 } \\
\text { - Idosos com } \\
\text { mais de } 80 \text { anos; } \\
\text { - Titulares de } \\
\text { cargos políticos } \\
\text { e de órgáos de } \\
\text { soberania (2000 } \\
\text { doses). } \\
\text { TERCEIRA: } \\
\text { - Pessoas de } \\
\text { idade } \geq 50 \text { anos, } \\
\text { com pelo menos } \\
\text { uma das } 4 \text { pato- } \\
\text { logias previstas } \\
\text { no Plano. }\end{array}$ & $\begin{array}{l}\text { - Pessoal da li- } \\
\text { nha da frente das } \\
\text { instituiçóes de } \\
\text { saúde; } \\
\text { - Trabalhadores } \\
\text { nos postos fron- } \\
\text { teiriços; } \\
\text { - Pessoal da li- } \\
\text { nha da frente no } \\
\text { combate à epide- } \\
\text { mia; } \\
\text { - Pessoal da linha } \\
\text { da frente das ins- } \\
\text { tituiçóes de servi- } \\
\text { ços sociais; } \\
\text { - Pessoal docente } \\
\text { e trabalhadores } \\
\text { de instituiçóes de } \\
\text { ensino; } \\
\text { - Trabalhadores } \\
\text { de transportes } \\
\text { públicos; } \\
\text { - Tripulaçáo de } \\
\text { aviação; } \\
\text { - Trabalhadores } \\
\text { em contacto com } \\
\text { alimentos da da } \\
\text { cadeia de frio e } \\
\text { produtos alimen- } \\
\text { tares frescos; } \\
\text { - Motoristas de } \\
\text { carga transfron- } \\
\text { teiriça; } \\
\text { - Tripulaçâo de } \\
\text { navios; } \\
\text { - Trabalhadores } \\
\text { da indústria da } \\
\text { pesca; } \\
\text { - Trabalhadores } \\
\text { da indústria do } \\
\text { turismo e do } \\
\text { jogo; } \\
\text { - Pessoas com } \\
\text { necessidade ur- } \\
\text { gente de se des- } \\
\text { locarem a países } \\
\text { ou regiōes endé- } \\
\text { micas. }\end{array}$ \\
\hline
\end{tabular}




\begin{tabular}{|c|c|c|c|c|c|}
\hline & Angola & Brasil & Moçambique & Portugal & RAEM \\
\hline Base Legal & & $\begin{array}{c}\text { Medida provisó- } \\
\text { ria n. }{ }^{\circ} 1.026, \text { de } \\
6 \text { de janeiro de } \\
2021\end{array}$ & & $\begin{array}{c}\text { Portaria } \\
\text { n.o } 298-\mathrm{B} / 2020\end{array}$ & $\begin{array}{c}\text { Despacho } \\
\text { do Chefe do } \\
\text { Executivo } \\
\text { n. }{ }^{\circ} 27 / 2021\end{array}$ \\
\hline $\begin{array}{l}\text { Data da } \\
\text { Primeira } \\
\text { Inoculação }\end{array}$ & $02 / 03 / 2021$ & $17 / 01 / 2021$ & 08/03/2021 & $27 / 12 / 2020$ & $09 / 02 / 2021$ \\
\hline 2. ${ }^{\text {a }}$ Fase & $\begin{array}{l}\text { - Pessoas da fai- } \\
\text { xa etária entre os } \\
16 \text { e } 39 \text { anos de } \\
\text { idade }\end{array}$ & & $\begin{array}{l}\text { - Doentes com } \\
\text { diabetes não } \\
\text { abrangidos na } \\
\text { fase anterior; } \\
\text { - Reclusos e } \\
\text { funcionários das } \\
\text { prisóes; } \\
\text { - Populaçôes } \\
\text { residentes em } \\
\text { centros de aco- } \\
\text { lhimento; } \\
\text { Pessoas a viver } \\
\text { nas zonas urba- } \\
\text { nas, com mais de } \\
50 \text { anos. }\end{array}$ & $\begin{array}{l}04 / 2021 \text { - } \\
\text { - Pessoas de ida- } \\
\text { de } \geq 65 \text { anos (que } \\
\text { năo tenham sido } \\
\text { vacinadas previa- } \\
\text { mente); } \\
\text { - Pessoas entre os } \\
50 \text { e os } 64 \text { anos } \\
\text { de idade, inclu- } \\
\text { sive, com pelo } \\
\text { menos uma das } \\
\text { patologias elen- } \\
\text { cadas no Plano. }\end{array}$ & \\
\hline $3 .^{\text {a }}$ Fase & $\begin{array}{l}2022 \\
\text { - Menores de } 16 \\
\text { anos }\end{array}$ & & $\begin{array}{l}\text { - Pessoas em } \\
\text { centros de aco- } \\
\text { lhimento; } \\
\text { - Moradores de } \\
\text { comunidades ru- } \\
\text { rais com mais de } \\
50 \text { anos. }\end{array}$ & $\begin{array}{l}\text { - Toda a restante } \\
\text { populaçáo }\end{array}$ & \\
\hline 4. ${ }^{\mathrm{a}}$ Fase & & & $\begin{array}{l}\text { - Todos os outros } \\
\text { cidadãos, exceto } \\
\text { menores de } 15 \\
\text { anos e mulheres } \\
\text { grávidas }\end{array}$ & & \\
\hline
\end{tabular}

Relativamente à vacinação, não passou despercebida à Equipa a importância do impacto da escassez de vacinas, passível de afetar, em grande medida, sobretudo, Angola e Moçambique, países que albergam populaçóes particularmente vulneráveis e o Brasil, país que tem sofrido com o elevado número de infeções e mortes.

No mesmo sentido do que foi defendido na Declaración de la Redbioética UNESCO ${ }^{39}$, de fevereiro de 2021, a Equipa salienta que as vacinas são um bem comum da Humanidade, e que, no geral, as tecnologias mobilizadas na mitigação da SARS-CoV-2 são bens públicos globais. Compreendida a urgência na quebra de patentes das vacinas, é útil, não obstante, denotar que essa quebra não é garantia de facilidade

39 Declaración de la Redbioética UNESCO, fevereiro de 2021 
de acesso e universalização da administração de vacinas e poderia ser contraproducente.

Avaliando a concreta adoção de medidas práticas e institucionais, a Equipa pode oferecer, em Portugal, o exemplo da Universidade de Coimbra (e a Universidade de Lisboa), que adotou medidas para a proteção dos utentes/utilizadores, mas igualmente dos trabalhadores, instituindo o teletrabalho quando compatível com o exercício de funções, suspendendo, seguindo as orientaçóes do Governo, a atividade letiva presencial e, entre outras medidas, implementando projetos de rastreio da comunidade educativa ${ }^{40}$. Em Angola, entre as medidas identificadas para proteção de trabalhadores, destacam-se a disponibilização de álcool-gel, água e detergente para lavar as mãos, distanciamento suficiente, e medição constante da temperatura corporal. Um inquirido angolano com a área de atividade na Saúde, reporta que: "Uma das maiores dificuldades pretende-se com a insuficiência de meios (máscara, álcool gel, luvas, batas, e outros), obrigando os profissionais ao uso repetido e muitas vezes por tempo maior do que o recomendado.”.

Dos 37 inquiridos que responderam a estas duas questôes, todos assinalaram a adoção de medidas de proteção de utentes/utilizadores e trabalhadores. Relativamente a estes últimos, entre as medidas mais frequentes destacam-se o teletrabalho $(70 \%)$, rotatividade de trabalhadores (37\%), utilização de EPI (76\%) e disponibilização de álcool-gel (51\%). Outras medidas incluem a implementação de rastreios aleatórios, disponibilização de equipamentos digitais, fornecimento de pacotes de internet e telefone, apoio psicológico, medição frequente da temperatura corporal, dispensa de trabalho presencial para trabalhadores com fatores de risco (idade, comorbidades, grávidas e mães de crianças com idade igual ou inferior a 12 anos).

Por fim, quanto à Experiência adquirida na Resposta à Emergência de Saúde Pública Covid-19, os inquiridos, face a uma eventual futura pandemia, apresentaram algumas sugestôes para melhorar a situação nos seus países e instituiçóes: preparação de planos de contingência, realização de simulações de pandemia, e organização de stocks de EPI, entre outras soluçôes preventivas, como investir no setor da saúde, combater a desinformação, valorizar os profissionais de saúde, adotar políticas de

40 Para uma detalhada explanação das medidas adotadas, https://www.uc.pt/covid19 (último acesso a 11/02/2021). 
sustentabilidade, melhorar a prestação de cuidados de saúde primários, implementar mecanismos eficazes de diplomacia internacional para situaçôes pandémicas, descentralizar a tomada de decisão, etc.

Relativamente ao papel desempenhado pelas Comissóes de Ética, em Portugal, o Conselho Nacional de Ética para as Ciências da Vida, tem produzido várias Comunicaçóes com Tomadas de Posição quanto a diferentes aspetos éticos associados à Pandemia, incluindo uma Posição sobre a utilização de Aplicações Digitais Móveis para Controlo da Transmissão da Covid-19 e ainda uma Posição, de caráter mais genérico, sobre a "Situação de emergência de saúde pública pela pandemia Covid-19: Aspetos éticos relevantes". Um inquirido mencionou ainda uma série de Comunicados emitidos pela Ordem dos Médicos, alertando para os problemas enfrentados pelo SNS no decorrer da Pandemia, nomeadamente, para a falta de resposta dada aos doentes não-Covid prioritários. Afirmou o inquirido: "A Ordem dos Médicos criou um Gabinete de Crise para acompanhar a Pandemia. O Conselho Nacional de ética e Deontologia Médica (Órgão Consultivo do Conselho Nacional da OM) emitiu um conjunto de recomendaçóes éticas relacionadas com situações provocadas pela Covid-19. Foram produzidos 2 documentos sobre questóes éticas: um produzido pela Ordem dos Médicos sobre a admissão de doentes em Serviços de Medicina intensivos em contexto de falta de camas e outro produzido pela Comissão de Ética do meu hospital sobre a entrega de resultados de SARS-CoV-2 a profissionais de saúde não médicos.".

No Brasil, destacam-se as contribuiçóes da Comissão Nacional de Ética em Pesquisa (Conep), associada ao Conselho Nacional de Saúde (CNS), prevendo imediatamente uma tramitação de urgência para protocolos de pesquisa sobre a SARS-CoV-2 (Informe à Sociedade, de 31 de janeiro de 2020), emitindo ofícios para adaptar a sua atividade ao contexto Pandémico e fornecendo informaçóes para participantes de pesquisa de vacinas contra a Covid que sejam parte de grupos placebo (27 de janeiro de 2021).

Segundo um inquirido: "vários Conselhos posicionaram-se em relação às questóes ligadas à pandemia COVID-19, dentre os quais o Conselho Federal de Psicologia que regulamentou a prestação de serviços psicológicos por meio de Tecnologia da Informação e da Comunicação em tempos de pandemia. Em verdade, de um modo e de outro, os conselhos de ética posicionaram-se no sentido de orientar os profissionais 
de prestaçáo de serviço no tempo que durasse a pandemia. A Comissão Nacional de Ética em Pesquisa (Conep) orientou o Ministério da Saúde que adotasse determinadas medidas com o objetivo de minimizar os potenciais riscos à saúde e a integridade dos participantes de pesquisas, pesquisadores e membros dos Comitês de Ética em Pesquisa durante a pandemia causada pelo coronavírus SARS-CoV-2 (Covid-19).”.

Na RAEM existe a Comissão de Ética para as Ciências da Vida (artigo $11 .^{\circ}$ da Lei n.o 2/96/M, de 3 de Junho), cuja composição e competências estáo definidas pelo Decreto-Lei n. ${ }^{\circ}$ 7/99/M, de 19 de Fevereiro. Não foram registadas contribuições deste Órgão no contexto da Pandemia.

Apesar de identificadas recomendaçóes e pareceres, alguns inquiridos consideram o contributo destas Comissóes manifestamente insuficiente, sendo desejável que assumam um papel mais central no futuro.

Quanto à atuação de acordo com as recomendaçôes da OMS, relata-se que, embora os países/RA tivessem atuado em conformidade com essas recomendaçôes, a tempestividade dessa atuação variou de país para país, relatando os especialistas da Equipa em Angola e Moçambique que o encerramento de fronteiras, por exemplo, imediatamente após terem sido recebidos os alertas sobre a SARS-CoV-2, terá sido fundamental na mitigação da Pandemia, na sua fase inicial. $\mathrm{Na}$ opinião de alguns inquiridos é reprovável a décalage de tempo entre a emissão de orientaçóes por parte da OMS e a adoção de medidas nos países/RA estudados. Entendem alguns inquiridos que as recomendaçóes da OMS no sentido de reforçar o envolvimento de todos os atores políticos na resposta ao SARS-CoV-2 não foi seguida em Portugal, país no qual a DGS centralizou em si a competência de gestáo e divulgação de informação sobre a Pandemia, relegando para um segundo plano figuras importantes como Associaçôes, os próprios órgãos de administração dos Hospitais e os cidadãos, que têm contributos fundamentais para desenvolver e implementar estratégias de mitigação da Covid. 
